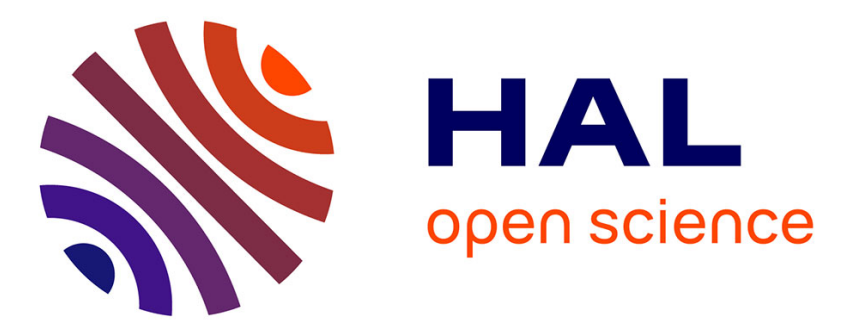

\title{
A methodology for regionalizing 3-D effective porosity at watershed scale in crystalline aquifers
}

Benoît Dewandel, Yvan Caballero, Jérôme Perrin, Alexandre Boisson, Fabrice Dazin, Sylvain Ferrant, Subash Chandra, Jean-Christophe Maréchal

\section{- To cite this version:}

Benoît Dewandel, Yvan Caballero, Jérôme Perrin, Alexandre Boisson, Fabrice Dazin, et al.. A methodology for regionalizing 3-D effective porosity at watershed scale in crystalline aquifers. Hydrological Processes, 2017, pp.2277 - 2295. 10.1002/hyp.11187 . hal-01573653

\section{HAL Id: hal-01573653 \\ https://hal.science/hal-01573653}

Submitted on 10 Aug 2017

HAL is a multi-disciplinary open access archive for the deposit and dissemination of scientific research documents, whether they are published or not. The documents may come from teaching and research institutions in France or abroad, or from public or private research centers.
L'archive ouverte pluridisciplinaire HAL, est destinée au dépôt et à la diffusion de documents scientifiques de niveau recherche, publiés ou non, émanant des établissements d'enseignement et de recherche français ou étrangers, des laboratoires publics ou privés. 


\title{
A methodology for regionalizing 3-D effective porosity at watershed scale in crystalline aquifers
}

\author{
Benoît Dewandel $^{1 *}$, Yvan Caballero ${ }^{1}$, Jérôme Perrin ${ }^{2}$, Alexandre Boisson ${ }^{2}$, Fabrice Dazin ${ }^{3}$, \\ Sylvain Ferrant ${ }^{4}$, Subash Chandra ${ }^{5} \&$ Jean-Christophe Maréchal ${ }^{1}$ \\ 1- BRGM, D3E/NRE Unit, 1039 rue de Pinville, 34000 Montpellier, France, \\ b.dewandel@brgm.fr \\ 2- BRGM, D3E/GDR Unit, 3 Av. C. Guillemin, 45100 Orléans, France, \\ 3- SIRS, 27 rue du Carrousel, Parc de la Cimaise, 59650 Villeneuve d'Ascq, France, \\ 4- CNRS; GET, 14 Avenue Edouard Belin 31400 Toulouse, France, \\ 5- Indo-French Centre for Groundwater Research, CSIR-NGRI, Uppal Road, Hyderabad \\ 500606, Telangana State, India. \\ * Corresponding author
}

\section{$\underline{\text { Abstract }}$}

An innovative approach for regionalizing the 3-D effective-porosity field is presented and applied to two large, overexploited and deeply weathered crystalline aquifers located in southern India. The method derives from earlier work on regionalizing a 2-D effectiveporosity field in that part of an aquifer where the water table fluctuates, which is now extended over the entire aquifer using a 3-D approach. A method based on geological and geophysical surveys has also been developed for mapping the weathering profile layers (saprolite and fractured layers). The method for regionalizing 3-D effective porosity combines: water-table fluctuation and groundwater budget techniques at various cell sizes with the use of satellite based data (for groundwater abstraction), the structure of the weathering profile and geostatistical techniques. The approach is presented in detail for the Kudaliar watershed $\left(983 \mathrm{~km}^{2}\right)$, and tested on the $730 \mathrm{~km}^{2}$ Anantapur watershed. At watershed scale, the effective porosity of the aquifer ranges from $0.5 \%$ to $2 \%$ in Kudaliar and between $0.3 \%$ and $1 \%$ in Anantapur, which agrees with earlier works. Results show that: i) depending on the geology and on the structure of the weathering profile, the vertical distribution of effective porosity can be very different, and that the fractured layers in crystalline aquifers are not necessarily characterized by a rapid decrease in effective porosity; and ii) that the lateral variations in effective porosity can be larger than the vertical ones. These variations suggest that within a same weathering profile the density of open fractures and/or degree of weathering in the fractured zone may significantly varies from a place to another.

The proposed method provides information on the spatial distribution of effective porosity which is of prime interest in terms of flux and contaminant transport in crystalline aquifers. Implications for mapping groundwater storage and scarcity are also discussed, which should help in improving groundwater resource management strategies.

Key words: Effective porosity, regionalization of aquifer parameters, upscaling, hard-rock aquifer, crystalline aquifer 


\section{Introduction}

Among the most important data for groundwater management or for reliable hydrogeological modelling, are accurate estimates of the spatial variation of hydrogeological properties, especially effective porosity and hydraulic conductivity. Data on spatial- and depth-variations of the effective porosity are important issues for contaminant transport, and particularly - as combined with the aquifer geometry - they provide an accurate image of the groundwater storage of an aquifer, thus valuable information for groundwater management issues.

In crystalline (granite and metamorphic rocks) aquifers, the regionalization of hydrogeological properties (i.e. estimating their spatial distribution) is further complicated, because of their strong natural heterogeneity. Various degrees of fracturing and connection between fracture networks induce strong variations of hydrogeological properties at all scales (e.g., Paillet, 1998; Maréchal et al., 2004; Le Borgne et al., 2004, 2006). The few available works on upscaling and regionalizing aquifer parameters in crystalline aquifers has mainly focused on transmissivity or hydraulic conductivity mapping, based on hydraulic-test data (Razack and Lasm, 2006; Chandra et al., 2008), classified transmissivity (indexed) maps, or potential aquifer-zone maps (Krásný, 1993, 2000; Lachassagne et al., 2001; Darko and Krásný, 2007; Madrucci et al., 2008; Dhakate, et al., 2008; Courtois et al., 2010).

Over the past three decades, the geological and hydrogeological characterization of crystalline aquifers has seen significant improvements (Chilton and Foster, 1995; Taylor and Howard, 2000; Lachassagne et al., 2011, 2015; Wyns et al., 2004, Maréchal et al., 2004; Dewandel et al., 2006; Ayraud et al., 2008; Guiléneuf et al., 2014; Roques et al., 2014a). These works show that, where such hard-rocks are exposed to deep weathering processes, the geometry and hydrodynamical properties of aquifers are closely related to the weathering grade of the parent rock. In granite-type rocks, including gneiss, a typical weathering profile comprises two main stratiform layers sub-parallel to the paleo-surface at the time of weathering processes (e.g. Wyns et al., 1999 and 2004, Krásný and Sharp, 2007; Maréchal et al., 2007, Reddy et al., 2009, Lachassagne et al., 2011, etc.). From top to bottom they are: (i) the saprolite layer, a sandy-clayey to clayey-sandy material usually characterized by low hydraulic conductivity and high effective porosity; (ii) the fractured layer, characterized by a depth decrease in the number of fractures (Houston and Lewis, 1998; Howard et al., 1992; Maréchal et al., 2004; Wyns et al., 2004; Dewandel et al., 2006) and usually low effective porosity. The underlying unfractured and fresh bedrock is only locally permeable and most authors consider that hydraulic conductivity is related to local tectonic fractures with highly variable hydrodynamic properties (e.g., Pickens et al., 1987; Leveinen et al., 1998; Walker et al., 2001; Kuusela et al., 2003).

Based on this concept of a stratiform hard-rock aquifer, Dewandel et al. (2012) proposed a methodology for regionalizing effective porosity- and also hydraulic conductivity- at the watershed scale. The method is based on the concept that large-scale variations in hydraulic head may characterize large-scale properties. For the effective porosity, the method combines - at cell scale - water-table fluctuation and groundwater-budget techniques in the absence of recharge from rainfall, an aggregation method, and variogram based statistics and kriging techniques to allow a relevant mapping. The approach was tested on an unconfined granitic aquifer exposed to deep weathering, located in South India (Maheshwaram watershed, $53 \mathrm{~km}^{2}$ ). The resulting estimates were confirmed by hydraulic tests carried out on the area and by effective-porosity estimates at watershed scale (Maréchal et al., 2004, 2006; Dewandel et al., 2006, 2010). However, the developed method could only determine effective 
porosity values for that part of the aquifer where the water table fluctuates, but not for the entire aquifer.

The novelty of the present work consists in using satellite based data (for groundwater abstraction) and in developing an original approach that allows extending the effective porosity in 3-D to the entire aquifer while combining it with the structure of the weathering profile. A method for mapping the weathered layers (based on geological and geophysical surveys) is also developed.

Results are illustrated in detail for the Kudaliar $983 \mathrm{~km}^{2}$ unconfined granite aquifer exposed to deep weathering in southern India, State of Telangana (Fig. 1a). The method then was tested on another area with a more complex geology, the Anantapur watershed $\left(730 \mathrm{~km}^{2}\right.$, State of Andhra Pradesh, India; Fig. 1b), but this area suffers from a lack of available observations, especially concerning geology. Both watersheds are overexploited (CGWB, 2009). The main results are presented in the discussion and compared to the ones of Kudaliar.

The method for regionalizing 3-D effective-porosity field data requires knowledge of the lateral and vertical variations of the weathering-profile (saprolite and fractured zone) on a hectometric to kilometric scale, as well as spatial estimates of groundwater abstraction and seasonal water-level measurements. This study provides additional information of the spatial heterogeneity of effective-porosity values at catchment scale and with depth, which are rare information. The implications for mapping groundwater storage and scarcity in term of groundwater management issues are discussed as well.

\section{Field data}

\subsection{Location and climate}

The Kudaliar catchment $\left(983 \mathrm{~km}^{2}\right)$ lies $50 \mathrm{~km}$ north of Hyderabad in the Telangana region of Medak District, India (Fig. 1a). The area has a relatively flat topography with elevations ranging from 430 to $640 \mathrm{~m}$ above mean sea level and the absence of perennial streams.

The region has a semi-arid climate controlled by monsoon periodicity. The rainy season (Khariff) occurs from June to October and the dry season (Rabi) from November to May. Mean annual precipitation is about $880 \mathrm{~mm}$, of which about $90 \%$ falls during the rainy season. The mean annual temperature is $26^{\circ} \mathrm{C}$, but in summer (March to May) it can reach $45^{\circ} \mathrm{C}$. The area is rural and populated by about 303,000 inhabitants (Indian Census, 2001; Aulong et al., 2012).

\subsection{Geology}


The geology of the area is relatively homogeneous and consists of Archean biotite granite commonly found in the Hyderabad region (Fig. 1a, GSI, 2002). Locally, the granite is intruded by small pegmatite bodies (1- to 10-metre-wide veins striking N45-60), metre-wide dolerite dykes of several geological ages (2.5-1.6 Ga; GSI, 2002; striking N000, N045, $\mathrm{N} 100$ ), and a few other intrusives (adamellite-granodiorite and amphibolite-hornblende-biotite schist enclaves). The granite is affected by deep in-situ weathering resulting from multiphase weathering-erosion processes (Dewandel et al., 2006). The weathering profile is formed of two main layers: saprolite and a fractured layer. The saprolite layer is composed of a few metres of saprolite of sandy texture (sandy regolith) and a thick layer of laminated saprolite, characterized by an unusual network of preserved sub-horizontal and sub-vertical fractures partially filled by clay. Deeper down, fractured granite, where weathered granite and some clay partially fill decametre-wide sub-horizontal and sub-vertical fractures, constitutes the bottom layer of the weathering profile. This layer is tapped by bore wells for crop irrigation and domestic water supply (mean bore-well depth: 50-70 m). Below the fissured fractured layer, the granite is not fractured and is not considered as an aquifer (Maréchal et al., 2006; Dewandel, 2006, 2012).

\subsection{Groundwater and irrigation}

As in most of southern India, groundwater is the only perennial water resource and is exploited by a large number of private bore wells $(7,000$ to 10,000 in the area) for the irrigation of rice, vegetables (tomatoes, eggplant, lady's finger, chillies, etc.), maize, cotton, and a few other crops (sugar cane, pulses and oilseeds). Plots are watered using flooding and ray irrigation techniques. Well-discharge rates are generally low, ranging from less than $1 \mathrm{~m}^{3} / \mathrm{h}$ to, exceptionally, a few tens of $\mathrm{m}^{3} / \mathrm{h}$.

Land-use characterization at parcel scale was performed on LISS-4 and Spot-5 images (6 and $10 \mathrm{~m}$ spacing, respectively) for the 2009 rainy season and the following 2010 dry season, with training and validating ground data (Ferrant et al., 2014). During the 2010 dry season, $7.2 \%$ of the area was irrigated for rice, $6.8 \%$ for vegetables, $1.9 \%$ for maize, and $2.1 \%$ for other crops (Table 1). It results that about $18 \%$ of the entire watershed surface was used for irrigated crops. The remaining ground is covered by built-up areas, pasture, forest, agroforestry and barren rocky land (boulder area). During the 2010 rainy season, the total cultivated land covered $45 \%$ of the watershed and was mainly dominated by cotton (19\%; only $3 \%$ irrigated, Table 1$)$, maize $(15 \% ; 7 \%$ irrigated) and rice $(10 \%$, all irrigated). Field observations on crop cultivation and irrigation were conducted with farmers to get data on cropping calendars and stages, as well as on watering techniques. Crop watering, determined by bore-well flow rates in the irrigated area, varies from 9 to $12 \mathrm{~mm} /$ day according to crops and seasons. These results are similar to those measured on the Maheshwaram watershed located $90 \mathrm{~km}$ farther south (Dewandel et al., 2008). Groundwater also supplies domestic uses, which amount is based on census data (Census, 2001). Combined with land-use, such data on groundwater consumption allow computing the seasonal groundwater abstraction on the watershed (Table 1), which was about $121 \mathrm{~mm}$ during the 2010 dry season (or $120 \mathrm{Mm}^{3}$ ) and about $88 \mathrm{~mm}$ for the 2009 rainy season (or $87 \mathrm{Mm}^{3}$ ). These results are consistent with those found for the Maheshwaram watershed with its similar cropping pattern: $100 \pm 27 \mathrm{~mm}$ and $73 \pm 9 \mathrm{~mm}$ during the dry and rainy seasons, respectively (average over 2002-2005; Maréchal et al., 2006; Dewandel et al., 2010). These computations also show that $86 \%$ of the annual groundwater abstraction is used for rice irrigation (196 mm/year; $176 \mathrm{Mm}^{3} /$ year), whereas domestic use is less than $1.5 \%$. 
Water-table maps were drawn based on groundwater-level measurements from 104 bore wells (abandoned wells, i.e. never pumped) after the rainy season (November 2009, Fig. 2a) and at the end of the dry season (June 2010). Water levels are deep (20 m below ground level on average; Fig. 2b), mainly within the fractured layer, more or less parallel to the topographic surface, and are impacted by the pumping wells.

\section{Methods}

\subsection{Mapping the weathered layers}

Because establishing the geometry of the two main weathered layers (saprolite and fractured layers) is the first step of the method, layer-thickness investigations based on geological observations on outcrops and geophysical measurements were carried out.

Geological observations consisted in evaluating the saprolite thickness from dug wells. These very large wells $\left(>20 \mathrm{~m}^{2}\right)$, often deeper than $15 \mathrm{~m}$ and now dry because of receding water levels, are the only available exposures of the weathering profile. Generally, the deepest ones crosscut the top of the fractured layer, easily recognizable due to the presence of fractured granite at the bottom. About $250 \mathrm{dug}$ wells were identified, 230 of which were suitable for identifying the top of the fractured layer. Other geological observations defined the lithology and identified the area without saprolite cover (the 'Boulder Area', i.e. barren rocky area corresponding to outcrops of the fractured layer). The locations of geological observations are presented in the 'results section' (see Fig. 5a).

Geophysical measurements consisted in electrical resistivity logging carried out in abandoned bore wells for estimating the layer thicknesses of the weathering profile. The logging tool, a simple probe designed at the Indo-French Centre for Groundwater Research (IFCGR, Hyderabad), is composed of two active electrodes (i.e. current and potential) fixed at $1 \mathrm{~m}$ separation on the probe and two additional electrodes (current and potential) kept on the ground at a relatively infinite distance from the bore well. The probe was connected to a "SYSCAL Switch (Junior)" resistivity meter and used to log at every $0.5 \mathrm{~m}$ intervals in the saturated zone. True resistivity could not be computed because of lack of data on bore-well diameter and on water electrical conductivity. However, previous experiments carried out in the same granite with the same weathering profile (Maheshwaram watershed, $90 \mathrm{~km}$ from Kudaliar; Chandra et al., 2009, and the Choutuppal experimental hydrogeological park at $100 \mathrm{~km}$; Chandra et al., 2015) showed very small differences between apparent and true resistivity of the rock, and a very good consistency between the weathered-layer thicknesses estimated from resistivity logs and detailed bore-well geological logs. Thus, the apparent resistivity has been taken for estimating layer thicknesses of the weathering profile. Measurements were carried out on 39 bore wells in the Kudaliar watershed. Figure 3 shows an example of resistivity well logging where weathering profile layers are recognized. 


\subsection{Regionalizing 3-D effective porosity}

\subsubsection{Effective porosity for the zone where the water table fluctuates (2-D approach)}

Dewandel et al. (2012) developed an approach for estimating the effective porosity field for that zone of the aquifer where the water table fluctuates. It consists in combining the watertable-fluctuation method and groundwater budget for a dry season (i.e. without groundwater recharge) with an aggregation method implying computations at various cell sizes. Assuming negligible recharge, the change in groundwater storage of an unconfined aquifer during a dry period is (Schicht and Walton, 1961; Maréchal et al., 2006; Zaidi et al., 2007):

$$
\Delta s=S y * \Delta h=E T+Q-R F+q_{o f f}-q_{o n}+q_{b f}
$$

where $\Delta \mathrm{s}$ is the change in groundwater storage $(\mathrm{m}), \Delta \mathrm{h}$ is the water-table fluctuation $(\mathrm{m}), \mathrm{Sy}$ is the effective porosity (or aquifer specific yield) of the zone where the water table fluctuates (unit less), ET is the evaporation from the water table (m), Q is the abstraction of groundwater by pumping (well-discharge rate) $(\mathrm{m}), \mathrm{RF}$ is the irrigation return flow $(\mathrm{m})$, qon and qoff are groundwater flow in and out of the aquifer $(\mathrm{m})$, and $\mathrm{q}_{\mathrm{bf}}$ is groundwater base flow to streams and springs $(\mathrm{m})$.

Groundwater abstraction by pumping, Q, has been computed from the land-use map. The map has been aggregated on a 100x100 m cell grid, each cell corresponding to a specific cropping pattern and/or urban area. Knowing the groundwater consumption of each land-use category, the groundwater abstraction map could be computed (Fig. 2a). Irrigation return flow, RF, was calculated according to return flow coefficients of each groundwater use (ratio of water input over return flow to the aquifer); Table 2 gives the used return-flow coefficients (Maréchal et al., 2006; Dewandel et al., 2008). Each coefficient was thus applied to the corresponding groundwater use for the dry season, which allows computing the net groundwater abstraction Q-RF in each cell.

Some terms of Eq. (1) can be neglected. Due to deep water levels in the area, on average $20 \mathrm{~m}$ in 2009-2010 (Fig. 2b), ET is a very small component of the budget, typically less than $1 \mathrm{~mm} / \mathrm{y}$ (Dewandel et al., 2010) and can be neglected. In addition, the absence of perennial stream- and spring flow because of the disconnection between the water table and the hydrological network, leads to nil qbf. Therefore, Eq. (1) can be simplified, and Sy becomes:

$$
\mathrm{Sy}=\left(\mathrm{Q}-\mathrm{RF}+\mathrm{q}_{\mathrm{off}}-\mathrm{q}_{\mathrm{on}}\right) / \Delta \mathrm{h}
$$

Maréchal et al. (2006) and Dewandel et al. (2010) used Eq.2 for estimating Sy at the watershed scale for the part of the aquifer where the water table fluctuates. At this scale and because water table is a subdued replica of the topography, $\mathrm{q}_{\text {off }}$ and $\mathrm{q}_{\text {on }}$ were low-values and thus their balance could be neglected ( $\mathrm{q}_{\text {off }}-\mathrm{q}_{\text {on }} \sim 0$ ). Assuming a small size affected by pumping with known Q-RF and $\Delta \mathrm{h}$ values, $\mathrm{q}_{\text {off }}$ and $\mathrm{q}_{\text {on }}$ or their balance will not be negligible as the radius of influence of the pumping will be larger than the size of the cell. Therefore assuming for this example a nil $\mathrm{q}_{\text {off- }} \mathrm{q}_{\text {on }}$ will induce an overestimation of Sy in Eq.2. Conversely, if the cell size is larger than the radius of influence of the pumping, or a group of pumping wells, the whole of the pumped volume will be abstracted from this large cell. The proposed approached in Dewandel et al. (2012) is similar to a coarse-graining method, which means that the system is observed with decreasing number of cells whose size is increasing. Since the aquifer is heavily pumped for irrigation, the main component of water flow ( $Q$ and $R F$ ) is vertical, except near the pumping wells where horizontal flows are not negligible (i.e. qoff and $\mathrm{q}_{\mathrm{on}}$ ). Thus, horizontal flow may occur in a small cell, but should disappear or be 
counterbalanced as the cell size increases toward a particular threshold size, which depends upon the typical spacing between pumping wells (or group of pumping wells), as well as on local aquifer properties. Q-RF and $\Delta \mathrm{h}$ being known, but ' $\mathrm{q}_{\text {off-}}-\mathrm{q}_{\text {on }}$ ' (horizontal flows) unknown, the aim of the method is to optimize the cell size for which ' $\mathrm{q}_{\text {off }}-\mathrm{q}_{\mathrm{on}}$ ' is negligible compared to vertical flow (i.e. $\mathrm{Q}$ and $\mathrm{RF}$ ), by making a cluster of computations of groundwater budget using increasing cell sizes. When increasing the size of the cells where the computations are done, the average of the cell's Sy values decreases to become near-stabilized at a value corresponding to the average Sy of the area, i.e. the one obtained while considering the watershed as a single cell (Dewandel et al., 2012). This method allows estimating a threshold, beyond which Sy stabilizes and horizontal flow can be neglected, or becomes negligible compared to vertical flow. This threshold determines the minimal cell size from which a 2-D effective-porosity field (map) can be computed. However, this map provides estimates only for the zone where the water table fluctuates.

\subsubsection{3-D effective-porosity field}

Because of the mapping of the weathered layers, the part of the weathering profile, where the water table fluctuates is known; locally within the saprolite layer or at the top of the fractured layer, but also deeper (Fig. 4; Fig. 9). Therefore, each cell of the previous effective-porosity map is associated to a particular location within the weathering profile. Thus, for estimating the 3-D effective-porosity field, the system has been sliced according to the saprolitefractured layer interface. This allows differentiating the two major layers of the aquifer (saprolite and fractured layer) as well as differentiating Sy-estimates according to depth below (or under) the interface.

Depth-intervals were chosen according to the number of available data-at least 30 points to perform realistic geostatistical analyses-, but should not be too thin according to the vertical resolution of weathered thickness maps. In the present case, a minimum of $5 \mathrm{~m}$ was chosen and depth-intervals are the same over the entire watershed. We thus dispose of sets of Sy-estimates for several depth-intervals in the weathering profile. As each set does not cover the entire watershed, they were analysed (statistics, variogram analysis), and kriging was used to produce Sy field for each depth-interval. Because some zones of a depth-interval can be dry, maps do not systematically cover the whole watershed area (i.e. no computation for dry zones). The proposed technique is thus a 3-D Sy mapping based on Sy mapping of each depth-interval.

Finally, all Sy-depth-interval maps were aggregated to produce an average Sy map at the aquifer scale. This map can then easily be used for the computation of a groundwater storage map, defined as the amount of water that is present in the aquifer (amount=Sy*saturated thickness), or a 'scarcity' map defined as the ratio groundwater storage/groundwater abstraction.

\section{Results}

\subsection{Maps of the weathered layers}

\subsubsection{Saprolite layer}

Figure 5a shows the thickness of the saprolite layer based on geological and geophysical (resistivity logging in bore wells) observations using variogram analysis and kriging. The 
variogram shows that the data are spatially structured and that kriging results in a relevant map. A spherical model combined with a 'nugget effect' to account for random variability was necessary to fit the experimental variogram (nugget: 10, sill: 43 , length: $4500 \mathrm{~m}$ ). The nugget/sill ratio $(0.23)$ is relatively low, suggesting that the variable has a strong spatial dependency (Ahmadi and Sedghamiz, 2007). Saprolite thickness ranges from $0 \mathrm{~m}$ (boulder area) to $28 \mathrm{~m}$, and is on average $13 \mathrm{~m}$ thick at watershed scale. This result agrees with previous work in the same granite (10-16 m; Maheshwaram granite, Dewandel et al., 2006).

\subsubsection{Total weathering profile}

Resistivity well-logging in the 39 bore wells (Fig. 3) shows that the resistivity values of the saprolite layer ranges between a few to $100 \Omega \mathrm{m}$ with low variations with depth. For the fractured layer, averaged values range between a few hundred to $3000 \Omega \mathrm{m}$, with high variations between fractured zones (few tens to hundreds $\Omega \mathrm{m}$ ) and the poorly to unfractured granite (up to several thousands $\Omega \mathrm{m}$ ). The unfractured bedrock is characterized by the highest resistivity, 3000 up to $10,000 \Omega \mathrm{m}$, with minor depth-variations. For consistency, each saprolite thickness evaluated from these measurements was verified with the geological data from nearby dug wells. According to these measurements, bedrock depth-which corresponds to the total thickness of the weathering profile-varies from 26 to $66 \mathrm{~m}$ (average $43 \pm 10 \mathrm{~m}$ ) for saprolite thickness ranging between 9 and $34 \mathrm{~m}$ (average $19 \pm 6 \mathrm{~m}$ ). These relatively high variations determined at local scale make it, however, difficult to directly map the layer thicknesses over the entire watershed.

For each of the 39 well-logging locations, the saprolite thickness was plotted against the entire weathering-profile thickness (Fig. 5c). Results show that the two parameters are linearly related according to the following relationship:

$$
\text { Tot_weath_thick. }=1.42( \pm 0.14) \times \text { Sapro_thick }+17.0( \pm 2.8)
$$

where Sapro_thick is the saprolite thickness (m) and Tot_weath_thick. the thickness of the entire weathering profile $(\mathrm{m})$. The values between brackets give the $95 \%$ confidence interval.

The linear regression coefficient, $\mathrm{R}^{2}$, is 0.75 , indicating that this relationship is robust enough for estimating bedrock depths at the 230 dug-well locations where saprolite thickness was estimated by geological surveying. For the boulder area (145 points), since saprolite is absent, the fractured layer is thus fixed at $17 \mathrm{~m}$ thick according to Eq. (3).

Figure $5 \mathrm{~b}$ presents the total weathering-profile thickness map. A spherical variogram model combined with a 'nugget effect' (nugget: 17, sill: 89, length: $4800 \mathrm{~m}$ ) was used. The nugget/sill ratio (0.19) again shows a strong spatial dependency, probably due to the spatial continuity of weathering processes at the watershed scale. Weathering-profile thickness ranges from $17 \mathrm{~m}$ (boulder area) to $56 \mathrm{~m}$, and is on average $35 \mathrm{~m}$. This result agrees with Maheshwaram granite (26-38 m; Dewandel et al., 2006).

\subsection{Effective porosity}

4.2.1. Effective porosity for the zone where the water table fluctuates (2-D approach) 
The water-table fluctuation map $(\Delta \mathrm{h})$ and net groundwater abstraction (Q-RF) were computed. Figure 6 shows the $\Delta \mathrm{h}$ map and Q-RF (here on a 1250x1250 m cell-size grid) between November 2009 and June 2010 (dry season). The $\Delta \mathrm{h}$ map is based on 104 mutual water-level-observation locations and standard kriging techniques (variogram model: spherical, sill: 9.3 , length $2800 \mathrm{~m})$. Mean $\Delta \mathrm{h}$ is $4.8 \mathrm{~m}( \pm 1.3 \mathrm{~m})$ at the watershed scale, and Q$\mathrm{RF}$ varies from 0 (mainly boulder area) to $310,000 \mathrm{~m}^{3}$ (1250x $1250 \mathrm{~m}$ cell-size grid). At the watershed scale, Q-RF is $68 \mathrm{Mm}^{3}$, or $68.9 \mathrm{~mm}$ (Table 3).

According to the proposed method, $\Delta \mathrm{h}$ and $\mathrm{Q}-\mathrm{RF}$ were computed for seven cell sizes $(\mathrm{Q}-$ $\mathrm{RF}$ and $\Delta \mathrm{h}$ maps being re-established for each cell size), whose sizes varied from 100x100 m to $2150 \times 2150 \mathrm{~m}$. Computations of Sy with Eq. (2) on the seven grids were followed by establishing Sy maps for each grid. Figure 7 presents the analysis of the impact of cell size on the Sy values (arithmetic average, standard deviation, maximum and minimum values, median, outliers, etc.). The arithmetic average shows a relatively flat trend: for small cell sizes the value is about 0.011 and then slightly increases to reach a plateau at 0.013 for cell sizes roughly larger than $1000 \times 1000 \mathrm{~m}$. This plateau value is very close to that obtained within the same granite and weathering profile in the Maheshwaram watershed $(0.014 \pm 0.003$, Maréchal et al., 2006; Dewandel et al., 2010, 2012).

The expected decrease in arithmetic average at watershed scale with increasing cell size is not observed, probably because the location of groundwater abstraction points results from a land-use rather than a bore-wells database as in Dewandel et al. (2012); this point will be discussed later. However, the number of outliers rapidly decreases when increasing the cell size for computation. In statistical terms, these extreme values fall outside the main normal distribution of the dataset, which may be due to very high data variability, or to abnormal values (experimental error). These high Sy values, exceeding 7-10\%, can be considered as unrealistic for such aquifers, particularly in the fractured zone where Sy does not exceed a few percent (e.g. Maréchal et al., 2004; Dewandel et al., 2012); they thus correspond to cases where horizontal flow ( $\mathrm{q}_{\text {off }}-\mathrm{q}_{\text {on }}$ ) cannot be neglected. Therefore, outliers can be considered as abnormal values indicative of cell-sizes with significant horizontal flows. The number of outliers starts to disappear for cell-sizes over $800 \times 800 \mathrm{~m}$, suggesting that beyond this size horizontal flows can be neglected and that Sy values can be used for mapping.

Sy map was drawn for cells of 1250x1250 m (Fig. 8). Variogram analysis shows a strong spatial dependency of the data (variogram model: exponential, sill: $3.7 \times 10^{-5}$, length: $4800 \mathrm{~m}$ ). Sy values range between $10^{-4}$ and 0.037 , with an average of $0.013( \pm 0.007)$.

\subsubsection{3-D effective-porosity field}

A N-S cross section of the Kudaliar watershed (Fig. 9) shows the aquifer interval where the water table fluctuates and thus the interval in which Sy-values were mapped (cell-size: 1250x1250 m, Fig. 8). According to the methodology described above, each Sy-value was associated to its location in the weathering profile: about $9 \%$ of Sy-values lie in the saprolite layer (51 data or cells) and 91\% in the fractured layer (533 data), because mainly the fractured layer is saturated. As the number of Sy-values in the saprolite layer is relatively low and as estimates are provided for the first $10 \mathrm{~m}$ - the reference level is at the interface 'saprolitefractured layer' - only one layer $(0-10 \mathrm{~m})$ was considered. This depth-interval has an averaged saturated thickness of $2.8 \pm 1.7 \mathrm{~m}$. For the fractured layer, the system has been sliced into five depth intervals. The first four intervals are: 0-5 m (139 data), 5-10 m (217 data), 10$15 \mathrm{~m}$ (145 data) and 15-22 $\mathrm{m}$ (32 data), the last layer being slightly thicker in order to gather 
enough data (at least 30; see above). Corresponding saturated thicknesses are $2.7 \pm 1.7 \mathrm{~m}$ for the first, $3.6 \pm 1.7 \mathrm{~m}$ for the second, $4.5 \pm 1.1 \mathrm{~m}$ for the third, and $6.5 \pm 1.3 \mathrm{~m}$ for the fourth depth-interval. Because water-table fluctuation does not provide information on Sy in places where the fractured zone is thicker than $22 \mathrm{~m}$, a linear interpolation was based on average Syvalues of each upper depth interval. This last, fifth, depth interval (>22 m) concerns 396 cells, but corresponds to a small thickness at aquifer scale, $1.8 \pm 2.0 \mathrm{~m}$, and low Sy values (Fig. 10a). Sy values in the saprolite layer and in the first three depth intervals of the fractured layer (0-5 to $10-15 \mathrm{~m}$; Fig. 10a) follow a similar normal distribution with comparable average values (0.014) and standard deviations (0.006 to 0.007). Sy values in the $15-22 \mathrm{~m}$ depth-interval again follow a near-normal distribution, but with a lower average (0.010), and Sy in the last layer ( $22 \mathrm{~m}$ down to unfractured rock) is also characterized by a near-normal distribution and an average of 0.005. The Sy-value variograms for each depth interval (Fig. 10a) show a strong to moderate spatial dependency of Sy, with a nugget/sill ratio varying from 0 to 0.49 . However, we cannot be certain of this point because of the absence of data over the short distance (1 250-m cell size) used for the computation.

Figure 10b shows the resulting Sy maps. Maps for the depth-intervals 0-5 m, 5-10 m, 10$15 \mathrm{~m}$ and 15-22 $\mathrm{m}$ were established using standard kriging techniques. The two other maps (saprolite layer and $22 \mathrm{~m}$ down to unfractured rock) did not require such techniques as a Sy value was available for all grid cells.

\section{Discussion}

To test its validity, the proposed approach was also applied to the $730 \mathrm{~km}^{2}$ Anantapur watershed. Though fewer geological field observations are available for this watershed, all other data are similar in terms of density, such as land-use at parcel scale and 130 points for water-table measurements. The main information concerning this watershed is provided as 'supplemental materials'.

\subsection{Mapping the weathering profile}

In the Kudaliar watershed, a linear relationship (Eq. 3) between saprolite thickness and the total weathering-profile thickness was founded. This relationship was used for estimating the total weathering-profile thickness at the watershed scale. This relationship is however empirical and, a priori, only valid for this particular weathering profile. The fairly good relationship also suggests that the weathering profile in the area is unique; otherwise relations would have been different from place to place. This relation also agrees with the observed weathering profile in the Maheshwaram watershed (same geology; Dewandel et al., 2006).

In the Anantapur watershed, a linear relationship was also found (Tot_weath_thick. $=3.51[ \pm 0.70]$ xSapro_thick $+13.6[ \pm 5.2] ; \mathrm{R}^{2}=0.78 ; 9$ points) but different from the one established in the Kudaliar area. Saprolite layer is thinner, on average $5 \pm 4 \mathrm{~m}$ thick at watershed scale, resulting in a total weathering profile of $31 \pm 13 \mathrm{~m}$ thick, thinner than in Kudaliar. Two main reasons may explain these differences, lithology and structure. The Anantapur watershed rocks, containing less biotite, are probably less affected by weathering (Eggler et al., 1969; Ledger and Rowe, 1980; Wyns et al., 2015), and the structural deformation of the rocks there-dominated by highly foliated gneisses - may further limit the deepening of the weathering front. Additionally, differences may come from different weathering-erosion contexts, one watershed having been more exposed to weathering or erosion because of landscape rejuvenation of the Indian peninsula (Radakrishna, 1993). 


\subsection{Effective porosity}

\subsubsection{Effective porosity within the water-table fluctuation zone of the aquifer}

The approach consists in investigating how the groundwater budget depends on cell size in the absence of recharge from rainfall (Eq. 2). When this is carried out where precise locations of groundwater abstraction (i.e. bore wells) are available, the arithmetic average of effective porosity (Sy) at watershed scale should decrease as the cell size increases, stabilizing around the mean value at watershed scale (Dewandel et al., 2012). Such stabilization starts from a particular threshold cell-size that depends on the water-level depression caused by groups of wells and local aquifer properties. In the Kudaliar watershed (Fig. 7), this decrease is not observed and Sy values stabilize rapidly around the mean watershed-scale value $(\mathrm{Sy}=0.013)$. But, as the number of Sy outlier values (here considered as abnormal data) decreases rapidly, it is possible to evaluate the threshold size.

In Kudaliar, groundwater abstraction data derive from a land-use map (100x100 m cells), thus assuming that a bore well and its irrigated land are located within the same cell. Therefore, the precise bore well locations are unknown. When groundwater budget is computed over small cells, land-use may indicate the presence of irrigated crops within the cell though the actual bore well is located in an adjacent cell. Therefore, for small cell sizes, some cells with high Q-RF and low $\Delta$ h that give high Sy values, and others with low Q-RF and high $\Delta \mathrm{h}$ that give low Sy values, both cases corresponding to what we identify as 'outliers'. This absence of accurate data on bore-well locations requires a significant increase of the cell size (over $800 \times 800 \mathrm{~m}$ ) in order to include in the same cell both area of groundwater use and corresponding pumping well, as well as water-level depressions caused by groups of wells making negligible horizontal flow balance (i.e. $\mathrm{q}_{\text {off- }} \mathrm{q}_{\mathrm{on}} \sim 0$ ). In the Maheshwaram watershed (Dewandel et al., 2012), the cell-size threshold was smaller $(520 \times 520 \mathrm{~m})$ as pumping-well locations were known. However, Sy maps based on computations performed on larger cell sizes $(800 \times 800 \mathrm{~m}$ and 1040x1040 m) were not significantly different from those based on a smaller cell-size, showing that increasing the cell-size for computation does not affect significantly the result. In Kudaliar though, the larger threshold size (over 800x800 m) still depends on water-level depression caused by groups of wells and local aquifer properties, but also on the technique used for estimating groundwater abstraction, and on the possible presence of land-use errors.

In the Anantapur watershed, the same investigations were carried out, and data analysis shows a decrease in the arithmetic average of Sy at watershed scale as the cell size increases, but only between the first two cell-sizes of computation $(100 \times 100 \mathrm{~m}$ to $500 \times 500 \mathrm{~m}$, Supplemental Materials). The number of outliers rapidly decreases to disappear for cell sizes larger than $1000 \times 1000 \mathrm{~m}$; this threshold size is similar to the one found in Kudaliar and computation were performed for cell-size of $1250 \times 1250 \mathrm{~m}$. At the watershed scale, the Sy value - for the zone where the water table fluctuates - is on average about 0.017 , a value relatively close to the Kudaliar one (0.013).

\subsubsection{3-D Effective porosity}

Figure 11a,b shows cross sections of Sy-values for both watersheds. In some places, Syvalues decrease with depth and in others Sy-value is almost homogeneous on a vertical scale. 
In crystalline aquifers, very few data are available on the vertical distribution of Sy. Estimates from Protonic Resonance Soundings (PRS) (Wyns et al., 2004; Baltassat et al., 2005; Vouillamoz, 2002, 2005, 2014) highlight a depth-decrease in Sy that is interpreted as a consequence of a depth-decrease in fracture density and grade of weathering. However, PRS measurements are made at the site scale (few tens of $\mathrm{m}^{2}$ ) and do not provide information on possible lateral variations at the watershed scale, or within the same weathering profile.

At the watershed scale (Fig. 11a,b), we found a major lateral variability in Sy values, suggesting that within a same weathering profile the density of open fractures and/or degree of weathering in the fractured zone may significantly vary from a place to another. Figure 12 shows how the average of Sy values varies according to depth in the weathering profile at watershed scale. For Kudaliar, Sy is almost constant from the last metres of the saprolite layer down to 12 to $15 \mathrm{~m}$ in the fractured zone (0.013 to 0.014$)$, then decreases to less than 0.005 for the deepest part of the fractured layer (20-25 m). At Anantapur, the Sy-depth variation is different: the saprolite layer on average is characterized by the higher porosity (about 0.04), followed by a rapid decrease within the first $15 \mathrm{~m}$ of the fractured layer $(<0.004$ for the depthinterval 10-15 m). Our results shows that, at watershed scale and depending on the geology and structure of the weathering profile, the vertical distribution of Sy can be very different, and that not all fractured zones in crystalline aquifers are necessarily characterized by a rapid depth-decrease in effective porosity, as is generally assumed.

Mean Sy-values for the entire saturated thickness were computed (Fig. 13), based on depth-interval Sy-maps and the corresponding saturated thickness of each layer. No clear relation with geology is observed. Only boulder areas, because of a less developed weathering profile (a few tens of metres of fractured zone), exhibit the lowest values regardless of the underlying geology. This absence of relation was also observed by Dewandel et al. (2012) for Sy values for the zone where the water table fluctuates - in an area covered by biotite- and leucocratic granite. This suggests that in granitic rocks the lateral Sy variability within the weathering profile can be more important than the Sy variability between rocks of the same group.

\subsection{Implications for mapping groundwater storage and scarcity}

The understanding of 3-D effective-porosity distribution provides new insights that can help explaining an observed local seasonal water-level decrease as well as a hydraulic disconnection in the aquifer because of pumping (Guiléneuf et al., 2014).

Combining the map of Sy values established for the entire saturated thickness (Fig. 13) with the thickness of the saturated aquifer, provides a groundwater storage map (Fig. 14a, c) and thus location of potential aquifers. Depth-variation of the groundwater storage at watershed scale is presented in Figure 15. Sy being higher in the Kudaliar watershed, the groundwater storage is higher as well, $175.2 \mathrm{Mm}^{3}$ (or $178 \mathrm{~mm}$ ) and relatively deep, with $84 \%$ between 5 and $22 \mathrm{~m}$ in the fractured layer (Fig. 15). In Anantapur, groundwater storage is lower at $107.3 \mathrm{Mm}^{3}$ (or $145 \mathrm{~mm}$ ), and rapidly decreases with depth, making this area more vulnerable to intensive pumping and drought as productive layers will be more rapidly desaturated. In both watersheds, the groundwater-storage values are nevertheless highly variable in space, ranging from over $450 \mathrm{~mm}$ where the weathering profile is thick and porous, to very low values where the profile is very thin (e.g. boulder areas) or of low porosity. 
With the objective of having a clear view on how aquifers are exposed to drought and pumping, a map showing water scarcity and vulnerability to overexploitation of the aquifer has been computed for each watershed (Fig. 14b, d). It is based on the ratio groundwaterstorage over net-annual-groundwater-abstraction (i.e., Q-RF), thus showing the duration in years of groundwater storage available with present abstraction rates - determined from landuse maps - and without recharge from rainfall, assuming thus successive low monsoons with insignificant recharge ( $<10 \mathrm{~mm}$ in 2004; Dewandel et al., 2010)). Such maps don't have the objective to predict where or during how many years groundwater can be pump, but to highlight how the degree of groundwater scarcity varies within watersheds. According to our commutations results show that on average groundwater storage corresponds to 2.2 years $( \pm 2.7)$ of pumping in Kudaliar and 3.9 years $( \pm 5.3)$ in Anantapur. Additionally, in Kudaliar $85 \%$ of the area has less than 3 years of storage while this is $70 \%$ in Anantapur.

This demonstrates that both watersheds are clearly exposed to drought because of intensive pumping, but that their exposure is contrasted. Even if the Kudaliar watershed has the greater aquifer reserve, it is the most exposed to groundwater scarcity because of intensive pumping. Net groundwater abstraction $\left(\mathrm{Q}-\mathrm{RF}_{\text {annual }}: 114 \mathrm{~mm}\right)$ is probably balanced by recharge from normal (110-120 mm/year; Dewandel et al., 2010, Perrin et al., 2012) and high monsoons, but not by low monsoons ( $<10 \mathrm{~mm}$ in 2004; Dewandel et al., 2010). At Anantapur, the area is drier-annual rainfall is $60 \%$ less than in Kudaliar - and also highly pumped. Even so, the years of available storage are on average significantly longer, indicating that the area is more subject to groundwater scarcity because of low monsoon recharge than, surprisingly, because of pumping. However, the northern part of the area is highly exposed to drought, with less than 2 years of groundwater storage. It seems that farmers at Anantapur have adapted their groundwater needs (irrigation, water supply) to what can be provided by the natural resource. This may have been induced by water-policy strategies and local experience of cultivation in a drier climate, motivating farmers to save groundwater for future dry years. This confirms that, even if groundwater storage is less, the adaptability of farmers to adjust their cropping patterns to bore-well yields and climate plays an important role in facing successive drought periods (Fishman et al., 2011; Aulong et al., 2012).

\section{Conclusions}

Mapping the weathered layer in crystalline aquifers is generally difficult, requiring a great surveying effort. Field work, based on geological observations and basic geophysical surveying (resistivity logging in bore wells), covered two large watersheds (Kudaliar, $983 \mathrm{~km}^{2}$, and Anantapur, $730 \mathrm{~km}^{2}$ ). The results show linear relationships between saprolite thickness and total-weathering-profile thickness that are a priori valid for one lithology in the same geological and weathering-profile context. They help in mapping the total weathering profile thickness. The maps are, however, valid at large scale (here 500x500 m) and do not consider local variations, for instance deepening of the weathering front because of local geological heterogeneity (faults, veins; Dewandel et al., 2011; Roques et al., 2014a\&b). In Anantapur, additional field data should be collected to determine if the relationship varies significantly according to the geology, which is more complex.

We show that alternative methods using basic field measurements and satellite remotesensing data can be used for regionalizing effective-porosity values in 3-D. The method is particularly interesting in fractured crystalline formations, where hydrodynamic-parameter 
datasets deduced from hydraulic tests are generally not available on enough locations to allow a relevant mapping.

The method is applicable to aquifers intensively pumped from numerous bore wells, requires a good knowledge of water-table variations in the absence of recharge and the weathering profile structure. At watershed scale, Sy-values for the saturated aquifer range from $0.5 \%$ to $2 \%$ in the Kudaliar watershed (1.3\% on average), and from $0.3 \%$ to $1 \%(0.6 \%$ on average) at Anantapur. The proposed method provides information on the spatial distribution of porosity that can be used in groundwater modelling and for testing the impact of climate change (Vigaud et al., 2012; Ferrant et al., 2014).

The 3-D effective-porosity field shows that lateral variations are generally more important than vertical ones, suggesting that, within a same weathering profile, the density of open fractures and/or the degree of weathering within the fractured zone (low-permeable but porous materials) may significantly vary from place to place. Our results also show that the vertical distribution of effective porosity within the fractured zone is not necessarily characterized by a rapid decrease in effective porosity.

No clear relationship was found between Sy and geology, indicating that, for these watersheds, lateral Sy variations within the same geology and weathering profile are more important than the variability in Sy between rocks of similar mineralogy exposed to the same weathering processes. However, both watersheds being mainly composed of granitoid rocks (granite and gneiss), we cannot exclude that other crystalline rocks, such as schist, or other weathering conditions, may present different behaviours.

The capability of producing groundwater-storage maps is very useful for establishing water-protection zones and improving groundwater-management policies. This last point is particularly important as, for example in India, water demand for agricultural and industrial development is increasing every year, which has led to the overpumping of numerous aquifers (e.g., Rodell et al., 2009; Tiwari et al., 2009) and may further increase the frequency of aquifer drought and scarcity (e.g. Kumar et al., 2005; CGWB, 2009). Thus, maps showing the ratio between groundwater-storage and net-annual-groundwater-abstraction are of prime interest for identifying the areas more exposed to groundwater scarcity. Results also show the capabilities of farmers to adapt their cropping pattern to their natural resource, and also that aquifer drought may occur more frequently in Kudaliar, which may lead to a further increase of the already high number of dry bore wells. In extreme cases, such as the low 2004 monsoon in Andhra Pradesh, this has led to bankruptcy and suicides, due to the failure of bore wells producing enough water to sustain crops (Maréchal, 2010).

Further research should confirm the linear dependency of saprolite thickness according to total-weathering-profile thickness, particularly over other hard-rock formations than granite (e.g. schist). The technique used for estimating the 3-D effective-porosity field should also be improved, particularly by developing techniques to refine the location of groundwater abstraction, adapted to areas without groundwater exploitation or applied to other hard-rock environments. Decision-support tools using the water-table-fluctuation and groundwaterbudget techniques at watershed scale (e.g., Dewandel et al., 2010) could be downscaled to cell size, for example by incorporating the 3-D Sy field, to predict water levels with variable agroclimatic scenarios and thus improve groundwater management. 


\section{Acknowledgements}

The authors are grateful to the research-sponsorship from BRGM (France), the Embassy of France in India, NGRI (India) and from the French National Research Agency (ANR) under the VMCS2008 program (SHIVA project $n^{\circ}$ ANR-08-VULN-010-01). Colleagues from NGRI and BRGM are thanked for their fruitful comments, discussions and technical assistance in the field. The two anonymous Journal referees are thanked for their useful remarks and comments that improved the quality of the paper. We are grateful to Dr. H.M. Kluijver for revising the English text.

\section{References}

Ahmadi, S.A., Sedghamiz, A., 2007. Geostatistical analysis of spatial and temporal variations of groundwater levels. Environ. Monit. Assess., 129, 277-294.

Ayraud, V., Aquilina, L., Labasque, T., Pauwels, H., Molenat, J., Pierson-Wickmann, A.C., Durand, V., Bour, O., Tarits, C., Le Corre, P., Fourre, E., Merot, P.J., Davy, P., 2008. Compartmentalization of physical and chemical properties in hard-rock aquifers deduced from chemical and groundwater age analyses. Appl. Geochem., 2008, 23 (9), 2686-2707.

Aulong, S., Chaudhuri, B., Farnier, L., Galab, S., Guerrin, J., Himanshu, H., Reddy, P.P., 2012. Are South Indian farmers adaptable to global change? A case in an Andhra Pradesh catchment basin. Reg. Environ. Chang. 12(3):423-436.

Baltassat, J.M., Legchenko, A., Ambroise, B., Mathieu, F., Lachassagne, P., Wyns, R., Mercier, J.L., Schott, J.-J., 2005. Magnetic resonance sounding (MRS) and resistivity characterisation of a mountain hard rock aquifer: the Ringelbach Catchment, Vosges Massif, France. Near Surf. Geophys. 3, 267-274.

CGWB, 2009. Dynamic Ground Water Resources of India. Ministry of Water Resources, Govt. of India, Central Ground Water Board.

Chandra, S., Atal, S., Nagaiah, E., Mallesh, D., Krishnam Raju, P., Anand Rao, V., Ahmed, S., 2009. Electrical Resistivity Tomography survey to test the performance of Multi-electrode Resistivity Systems (Syscal). Tech. Rep. No. NGRI-2009-GW-690.

Chandra, S., Ahmed, S., Ram, A., Dewandel B., 2008. Estimation of hard rock aquifers hydraulic conductivity from geoelectrical measurements: A theoretical development with field application. J. of Hydrology, 357, 218- 227.

Chandra S., Boisson A., and Ahmed S., 2015. Quantitative characterization to construct hard rock lithological model using dual resistivity borehole logging. Arab J. Geosci (2015) 8:3685-3696.

Chilton, P.J., Foster, S.S.D., 1995. Hydrogeological characterization and water-supply potential of basement aquifers in tropical Africa. Hydrogeology J., 3 (1), 36-49.

Courtois, N., Lachassagne, P., Wyns, R., Blanchin, R., Bougaïré, F.D., Somé, S., Tapsoba, A., 2010. Large-scale mapping of hard-rock aquifer properties applied to Burkina Faso, Ground Water, 48 (2), 269-283. 
Darko, Ph.K., Krásný, J., 2007. Regional transmissivity distribution and groundwater potential in hard rock of Ghana. In: Krásný J. \& Sharp J.M. (eds.): Groundwater in fractured rocks, IAH Selected Papers, 9, 1-30. Taylor and Francis.

Dewandel, B., Lachassagne, P., Wyns, R., Maréchal, J.C., Krishnamurthy, N.S., 2006. A generalized hydrogeological conceptual model of granite aquifers controlled by single or multiphase weathering. J. of Hydrology, 330, 260-284, doi:10.1016/j.jhydrol.2006.03.026.

Dewandel, B., Gandolfi, J.M., de Condappa, D., Ahmed, S., 2008. An efficient methodology for estimating irrigation return flow coefficients of irrigated crops at watershed and seasonal scales, Hydrological Processes, 22, 1700-1712.

Dewandel, B., Perrin, J., Ahmed, S., Aulong, S., Hrkal, Z., Lachassagne, P., Samad, M., Massuel S., 2010. Development of a tool for managing groundwater resources in semi-arid hard rock regions. Application to a rural watershed in south India. Hydrological Processes, 24, 2784-2797.

Dewandel, B., Lachassagne, P., Zaidi, F.K., Chandra, S., 2011. A conceptual hydrodynamic model of a geological discontinuity in hard rock aquifers: example of a quartz reef in granitic terrain in South India. J of Hydrology, 405, 474-487.

Dewandel, B., Maréchal, J.C., Bour, O., Ladouche, B., Ahmed, S., Chandra, S., Pauwels, H., 2012. Upscaling and regionalizing hydraulic conductivity and effective porosity at watershed scale in deeply weathered crystalline aquifers. J. Hydrology, 416-417, 83-97. doi:10.1016/j.jhydrol.2011.11.038.

Dhakate, R., Singh, V.S., Negi, B.C., Chandra, S., Ananda Rao V., 2008. Geomorphological and geophysical approach for locating favourable groundwater zones in granitic terrain, Andhra radish, India. J. Env. Management, 88, 1373-1383.

Eggler, D.H., Larson, E.E., Bradley, W.C., 1969. Granites, gneisses and the Sherman erosion surface, Southern Laramie Range, Colorado, Wyoming. Am. Jour. Sciences, 267, 510-522.

Ferrant, S., Caballero, Y., Perrin, J., Gascoin, S., Dewandel, B., Aulong, S., Dazin, S., Ahmed, S., Maréchal, J.C., 2014. Projected impacts of climate change on farmers' extraction of groundwater from crystalline aquifers in South India. Sci Rep 4:3697.

Fishman, R.M., Siegfried, T., Raj, P., Modi, V., Lall, U., 2011. Overextraction from shallow bedrock versus deep alluvial aquifers: reliability versus sustainability considerations for India's groundwater irrigation. Water Resourc. Res., 47, 175-179.

G.I.S., 2002. Geological Survey of India. Geological map: Hyderabad quadrangle - Andhra Pradesh.

Guihéneuf, N., Boisson, A., Bour O., Dewandel, B., Perrin, J., Dausse, A., Viossanges, M., Chandra, S., Ahmed, S., Maréchal, J.C., 2014. Groundwater flows in weathered crystalline rocks: impact of piezometric variations and depth-dependent fracture connectivity. J. Hydrol., $511,320-334$.

Houston, J.F.T., Lewis R.T., 1988. The Victoria Province drought relief project, II. Borehole yield relationships. Ground Water, 26(4), 418-426. 
Howard, K.W.F., Hughes, M., Charlesworth, D.L., Ngobi G., 1992. Hydrogeologic evaluation of fracture permeability in crystalline basement aquifers of Uganda. Appl. Hydrogeol. 1, 5565 .

Kumar, R., Singh, R.D., Sharma, K.D., 2005. Water Resources of India., Curr. Sci. India, 89(5), 794-811.

Krásný, J., 2000. Geologic factors influencing spatial distribution of hard rock transmissivity. In Sililo O. et al (eds): Groundwater: Past Achievements and Future Challenges. Proc. 30 IAH Congress, 2000, 187-191, Cape Town, Balkema, Rotterdam.

Krásný, J., Sharp, J.M., 2007. Hydrogeology of fractured rocks from particular fractures to regional approaches: state-of-the-art and future challenge. In: Krásný J. \& Sharp J.M. (eds.): Groundwater in fractured rocks, IAH Selected Papers, 9, 1-30. Taylor and Francis.

Kuusela-Lahtinen ,A., Niemi, A., Luukkonen A., 2003. Flow dimension as an indicator of hydraulic behaviour in site characterization of fractured rock. Ground Water, 41(3), 33-341.

Lachassagne, P., Wyns, R., Bérard, P., Bruel, T., Chéry, L., Coutand, T., Desprats, J.F., Le Strat, P., 2001. Exploitation of high-yield in hard-rock aquifers: Downscaling methodology combining GIS and multicriteria analysis to delineate field prospecting zones. Ground Water, 39 (4), 568-581.

Lachassagne, P. Wyns, R., Dewandel, B., 2011. The fracture permeability of hard rock aquifers is due neither to tectonics, nor to unloading, but to weathering processes. Terra Nova, 23 (3), 145-161. doi: 10.1111/j.1365-3121.2011.00998.x

Lachassagne, P. Wyns, R., Dewandel, B., 2015. The conceptual model of hard rock aquifers and its practical applications. Extended abstract at Vingtièmes journées techniques du Comité Français d'Hydrogéologie de l'Association Internationale des Hydrogéologues: Aquifères de socle : le point sur les concepts et les applications opérationnelles La Roche-sur-Yon, France, juin 2015.

Le Borgne, T., Bour, O., de Dreuzy, J.R., Davy, P., Touchard, F., 2004. Equivalent mean flow models for fractured aquifers: insights from a pumping test scaling interpretation. Water Resour. Res., 40, W03512, 1-12.

Le Borgne, T., Bour, O., Paillet, F.L, Caudal, J.P., 2006. Assessment of preferential flow path connectivity and hydraulic properties at single-borehole and cross-borehole scales in fractured aquifer. J. Hydrology, 328, 347-359.

Ledger, E.B., Rowe, M.W., 1980. Release of uranium from granitic rocks during in situ weathering and initial erosion (central Texas). Chem. Geol., .29, 227-248.

Leveinen, J., Rönkä, E., Tikkanen, J., Karro E., 1998. Fractional flow dimensions and hydraulic properties of a fracture-zone aquifer, Leppävirta, Finland. Hydrogeol. J.,6, 327-340.

Madrucci, V., Taioli, F., de Araujo C.C., 2008. Groundwater favourability map using GIS multicriteria data analysis on crystalline terrain, Sao Paulo State, Brazil. J. Hydrology, 357, 153-173.

Maréchal, J.C., Dewandel, B., and Subrahmanyam, K., 2004. Contribution of hydraulic tests at different scales to characterize fracture network properties in the weathered-fissured layer of a hard rock aquifers. Water Resourc. Res., 40, W11508. 
Maréchal, J.C., Dewandel, B., Ahmed, S., Galeazzi, L., 2006. Combining the groundwater budget and water table fluctuation methods to estimate specific yield and natural recharge. J. Hydrology, 329, 1-2, 281-293, doi:10.1016/j.jhydrol.2006.02.022.

Maréchal, J.C., Dewandel, B., Ahmed, S., Lachassagne, P., 2007. Hard-rock aquifers characterization prior to modelling at catchment scale: an application to India. In: Krásný J. \& Sharp J.M. (eds.): Groundwater in fractured rocks, IAH Selected Papers, 9, 1-30. Taylor and Francis.

Maréchal, J.C., 2010. Editor's message: the sunk cost fallacy of deep drilling. Hydrogeol. J 18:287-289.

Paillet, F.L., 1998. Flow modelling and permeability estimations using borehole flow logs in heterogeneous fractured formation. Water Resour. Res., 34 (5), 997-1010.

Perrin, J., Ferrant, S., Massuel, S., Dewandel, B., Maréchal, J.C., Ahmed, S., Aulong, S., 2012. Assessing water availability in a semi-arid watershed of southern India using a semidistributed model. J. Hydrol. 460-461, 143-155.

Pickens, J.F., Grisak, G.E., Avis, J.D., Belanger, D.W., Thury M., 1987. Analysis and interpretation of borehole hydraulic tests in deep boreholes; principles model development, and applications. Water Resour. Res., 23 (7), 1341-1375.

Radakrishna, B.P., 1993. Neogene uplift and geomorphic rejuvenation of the Indian Peninsula. Current Science, 64, 787-793.

Razack, M., Lasm, T., 2006. Geostatistical estimation of the transmissivity in a highly fractured metamorphic and crystalline aquifer (Man-Danane Region, Western Ivory Coast). J. Hydrol., 325, 164-178.

Reddy, D.V., Nagabhushanam, P., Sukhija, B.S., Reddy, A.G.S., 2009. Understanding hydrological processes in a highly stressed granitic aquifer in southern India. Hydrol. Process. $23,1282-1294$.

Rodell, M., Velicogna, I., Famiglietti, J.S., 2009. Satellite-based estimates of groundwater depletion in India. Nature, doi: 10.1038/natrue08238, 1-5.

Roques, C., Bour, O., Aquilina, L., Dewandel, B., Leray, S., Schroetter, J.M., Longuevergne, L., Le Borgne, T., Hochreutener, R., Labasque, T., Lavenant, N., Vergnaud-Ayraud, V., Mougin, B., 2014a. Hydrological behavior of a deep sub-vertical fault in crystalline basement and relationships with surrounding reservoirs. J. Hydrol. 509, 42-54. http://dx.doi.org/10.1016/j.jhydrol.2013.11.023.

Roques, C., Aquilina, L., Bour, O., Maréchal, J.C., Dewandel, B., Pauwels, H., Labasque, T., Vergnaud-Ayraud, V., Hochreutener, R., 2014b. Groundwater sources and geochemical processes in a crystalline fault aquifer. J. Hydrol., 519, 3110-3128. http://dx.doi.org/10.1016/j.jhydrol.2014.10.052.

Schicht, R.J., Walton, W.C., 1961. Hydrologic budgets for three small watersheds in Illinois, Illinois State Water Surv. Rep. Invest., 40, 40p.

Taylor, R., Howard, K., 2000. A tectono-geomorphic model of the hydrogeology of deeply weathered crystalline rock: evidence from Uganda. Hydrogeol. J., 8 (3), 279-294. 
Tiwari, V.M., Wahr, J., Swenson, S., 2009. Dwindling groundwater resources in northern India, from satellite gravity observations. Geophys. Res. Letters, 36, L18401, doi: 10.1029/2009GL039401. 1-5.

Vigaud, N., Vrac, M., Caballero, Y., 2012. Probabilistic downscaling of GCMs scenarios over southern India. Int. J. Climatol. 33, 1248-1263.

Vouillamoz, J.M., Descloitres, M., Bernard, J., Fourcassié, P., Romagny, L., 2002. Application of integrated magnetic resonance sounding and resistivity methods for borehole implementation, a case study in Cambodia. J. Appl. Geophys. 50, 67-81.

Vouillamoz, J.M., Descloitres, M., Toe, G., Legchenko, A., 2005. Characterization of crystalline basement aquifers with MRS: comparison with boreholes and pumping test data in Burkina Faso. Near Surface Geophysics 3 (3), 205-213.

Vouillamoz, J.M., Lawson, F.M.A., Yalob, N., Descloitres, M., 2014. The use of magnetic resonance sounding for quantifying specific yield and transmissivity in hard rock aquifers: The example of Benin. J. Appl. Geoph. 107, 16-24. http://dx.doi.org/10.1016/j.jappgeo.2014.05.012.

Walker, D.D., Gylling, B., Strom, A., Selroos J.O., 2001. Hydrogeologic studies for nuclearwaste disposal in Sweden. Hydrogeol. J., 9 (5), 419-431.

Wyns, R., Gourry, J.C., Baltassat, J.M., Lebert, F., 1999. Caractérisation multiparamètres des horizons de subsurface $(0-100 \mathrm{~m})$ en contexte de socle altéré, in 2ème Colloque GEOFCAN, ed. I. BRGM, IRD, UPMC, 105-110, Orléans, France.

Wyns, R., Baltassat, J.M., Lachassagne, P., Legchenko, A., Vairon, J., Mathieu, F., 2004. Application of SNMR soundings for groundwater reserves mapping in weathered basement rocks (Brittany, France), Bull. Soc. Géol. France, 175 (1), 21-34.

Wyns, R., Dewandel, B. Lachassagne, P., 2015. Origin of fracturation in hard-rock aquifers: what are the factors that control the properties of the fissured horizon? Extended abstract at Vingtièmes journées techniques du Comité Français d'Hydrogéologie de l'Association Internationale des Hydrogéologues: Aquifères de socle : le point sur les concepts et les applications opérationnelles La Roche-sur-Yon, France, June 2015.

Zaidi, F.K., Ahmed, S., Maréchal, J.C., Dewandel, B., 2007. Optimizing a piezometric network in the estimation of the groundwater budget: A case study from a crystalline-rock watershed in southern India, Hydrogeol. J., 15, 1131-1145. 


\section{Figure}

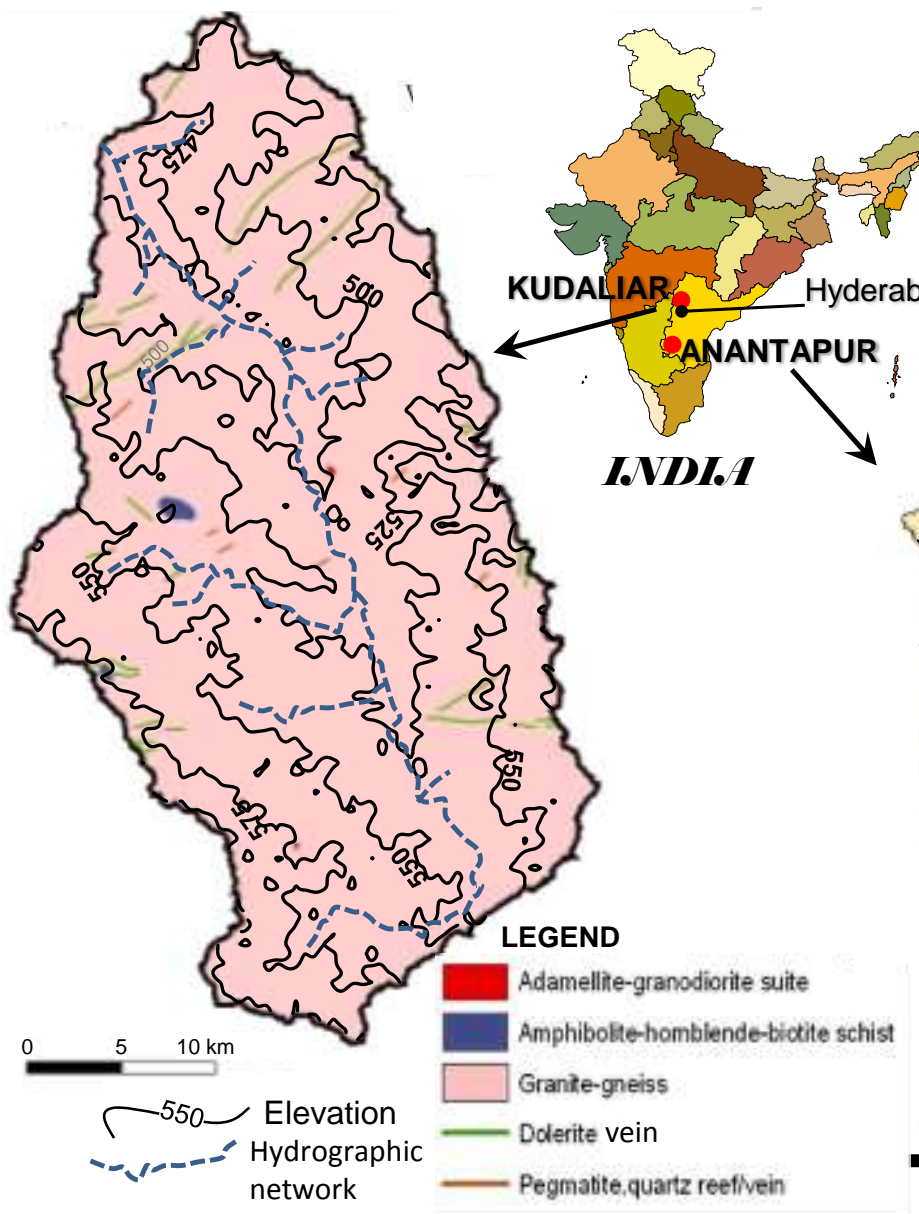

(a)

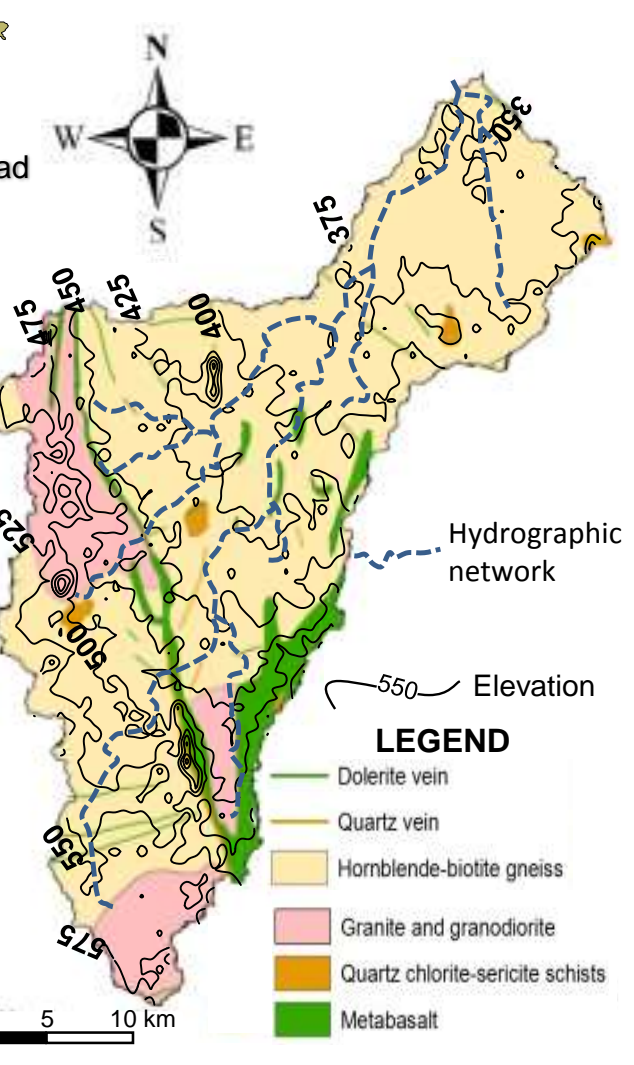

(b)

Figure 1. Geological maps of the Kudaliar and Anantapur watersheds (State of Telangana, India), and topographic levels (metres above sea level). Contour interval: $25 \mathrm{~m}$. 

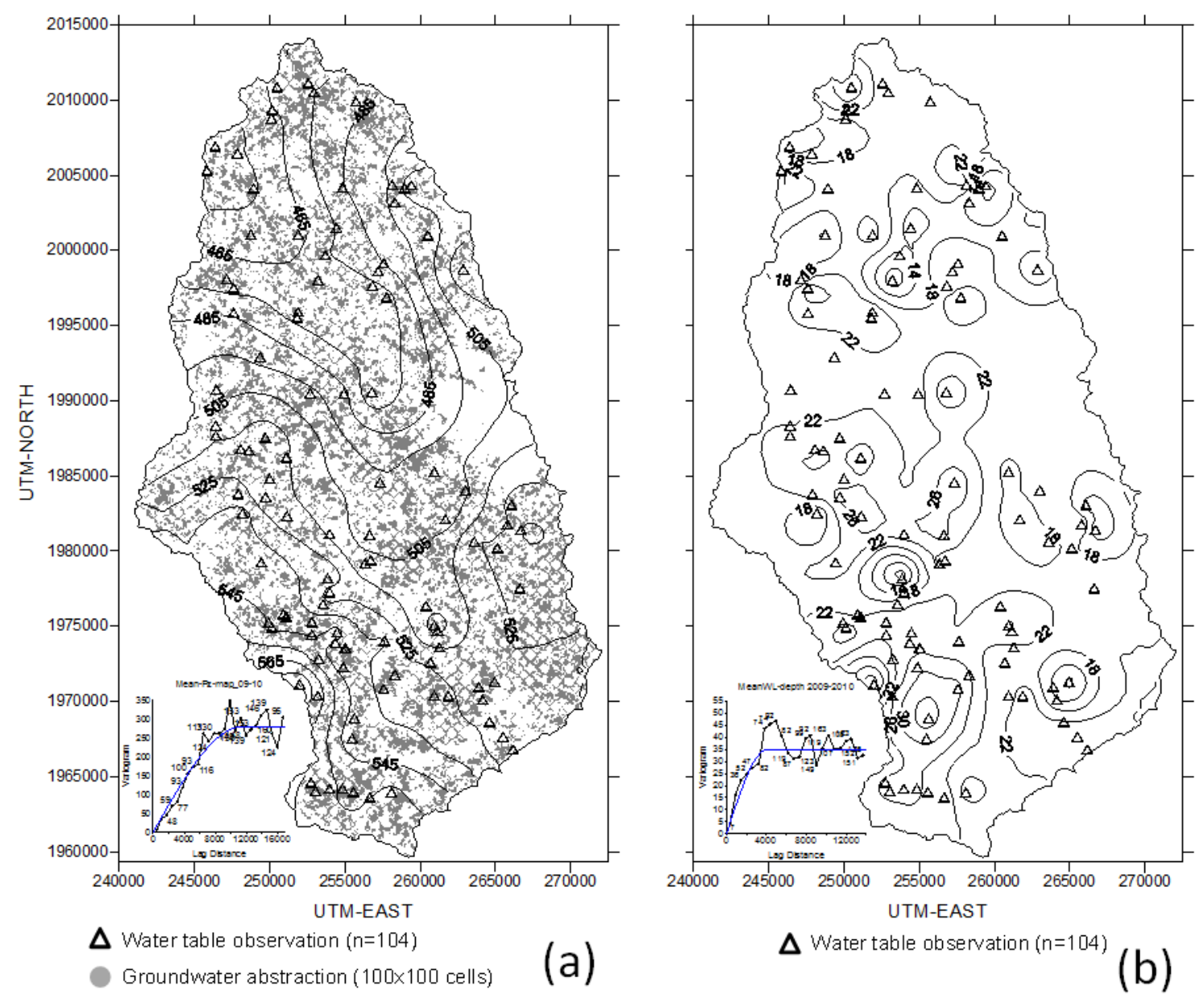

Figure 2. a) Mean water-table map (metres above sea level) ; contour interval: $10 \mathrm{~m}$ and b) Mean water-table depth map (metres; contour interval: $4 \mathrm{~m}$ ) of the Kudaliar watershed during the 2010 dry season. Location of observation (104) and pumping wells (cell size: 100x100 m) deduced from land-use at parcel scale are also presented. The inserts present the variograms used for data interpolation (water-table map= model: spherical, length: $11500 \mathrm{~m}$, sill: 280 ; water table depth map= model: spherical, length: $4100 \mathrm{~m}$, sill: 35 ). 


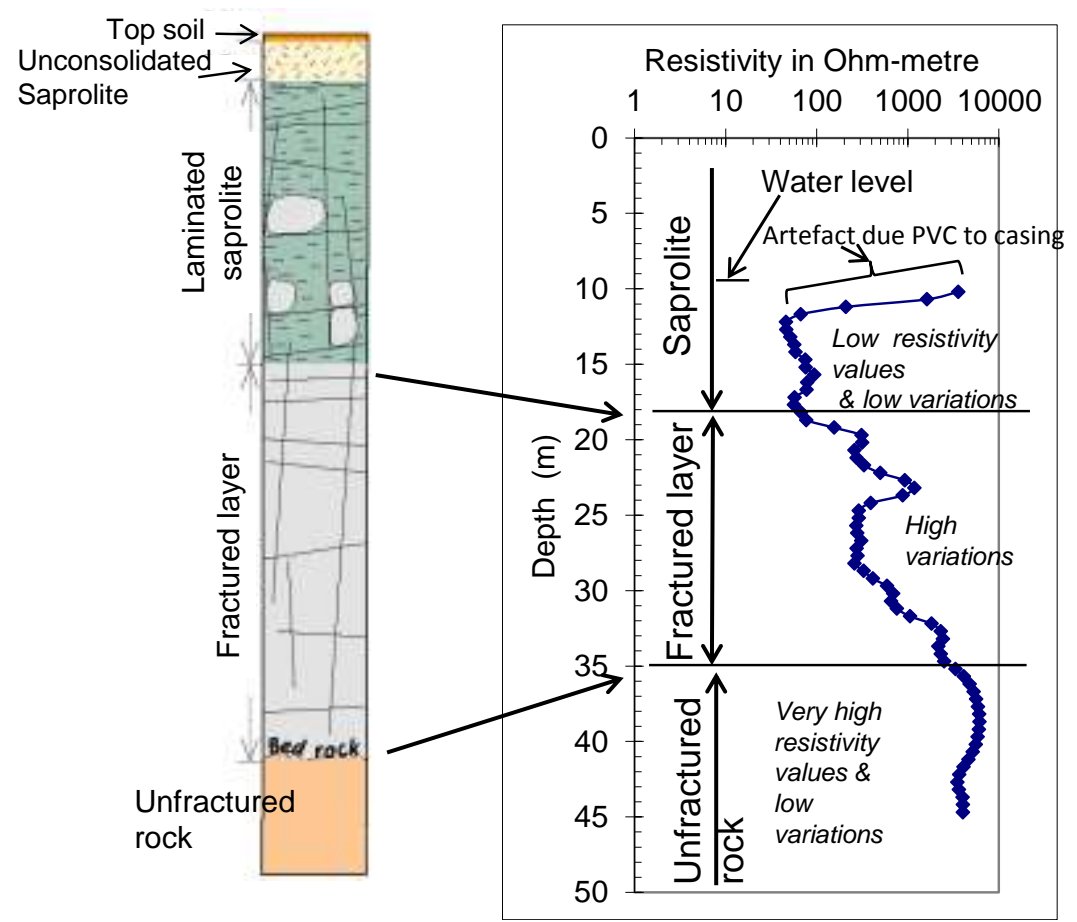

Figure 3. Example of electrical resistivity well logging (apparent resistivity) used for estimating the total thickness of the weathering profile; Kudaliar watershed.

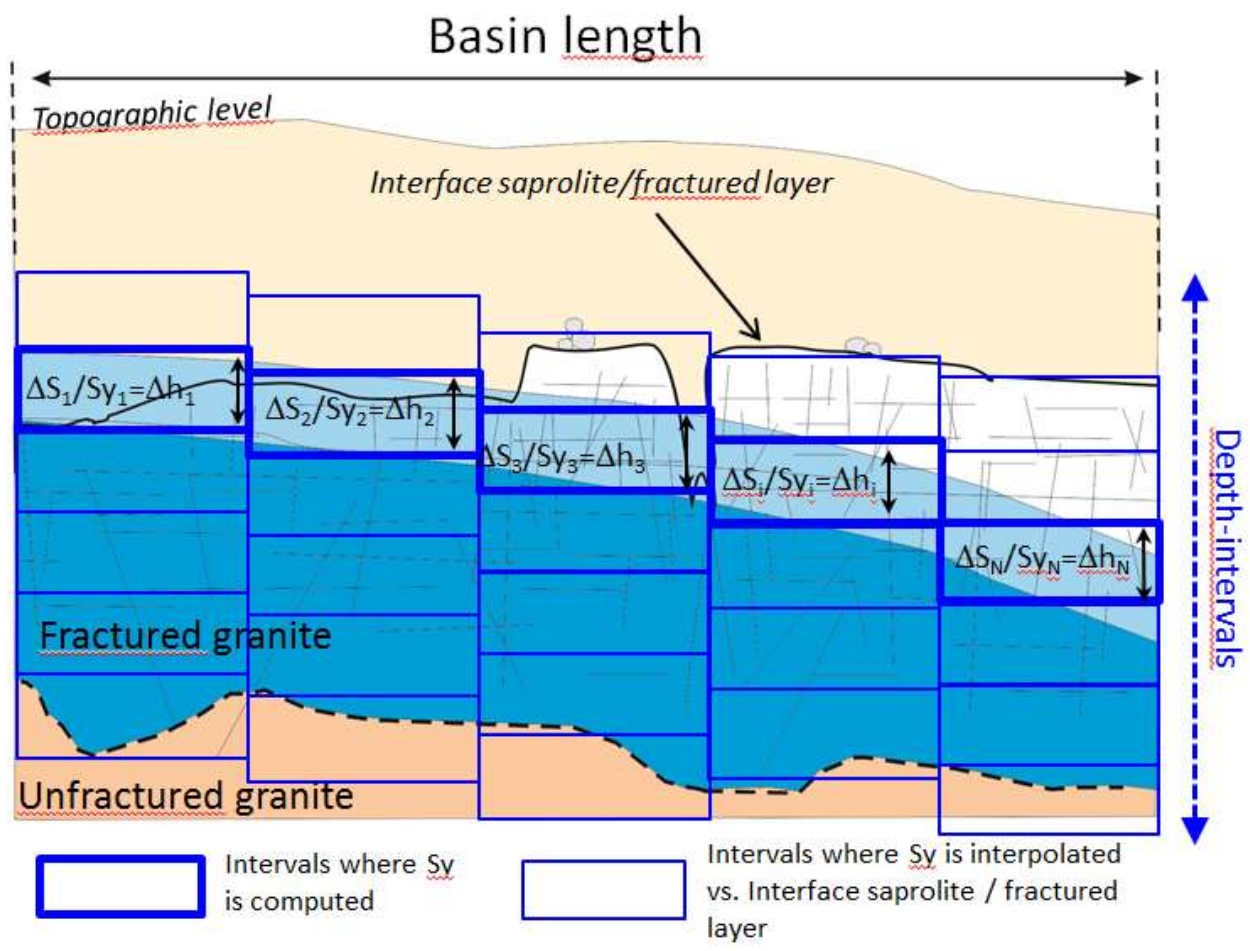

Figure 4. Sketch for computing the effective porosity (Sy) of each depth-interval according to the interface between saprolite and fractured layer. 

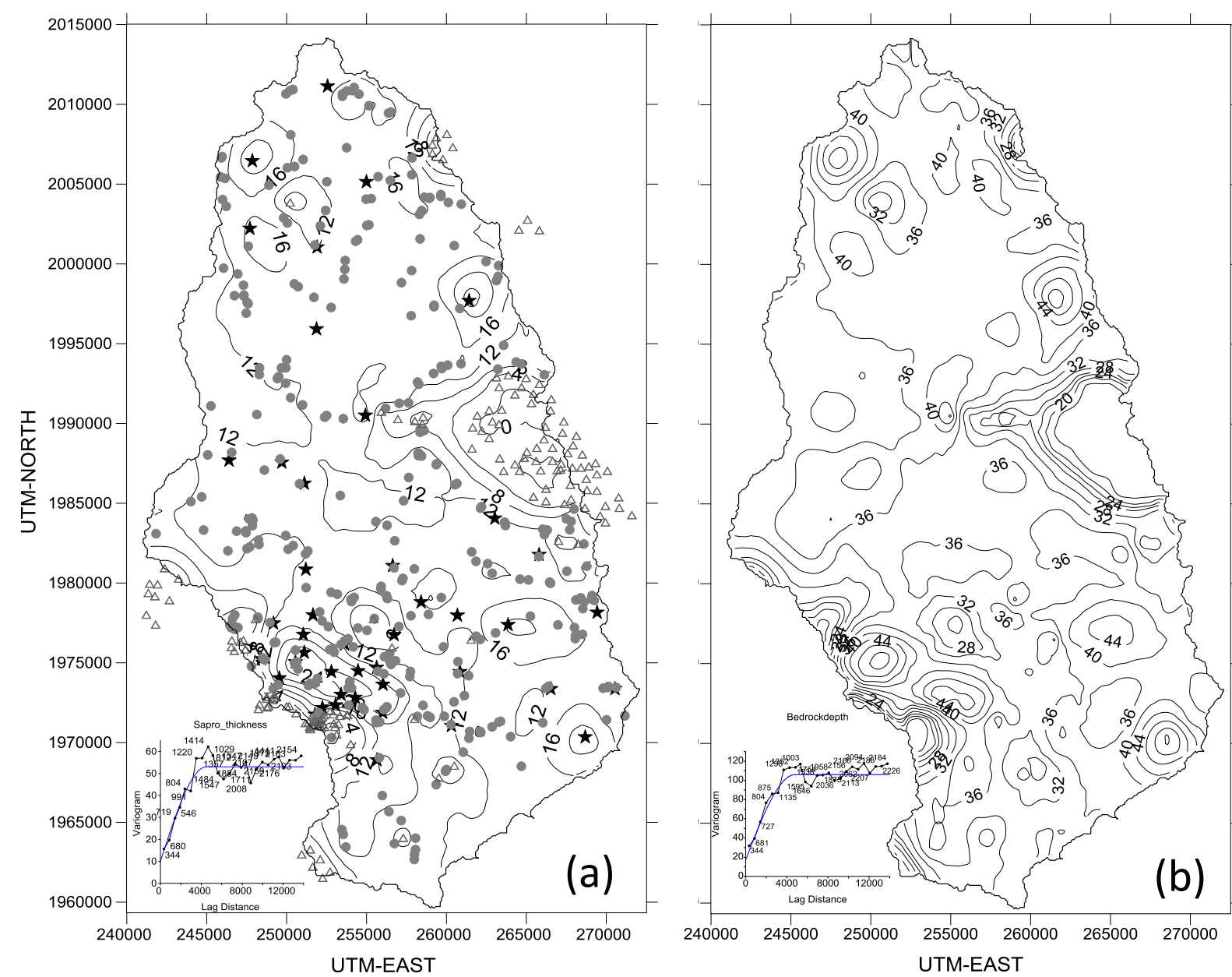

Geological survey: saprolite estimates $\triangle$ Boulders (large amount of fresh rock) $\star$ Geophysical log

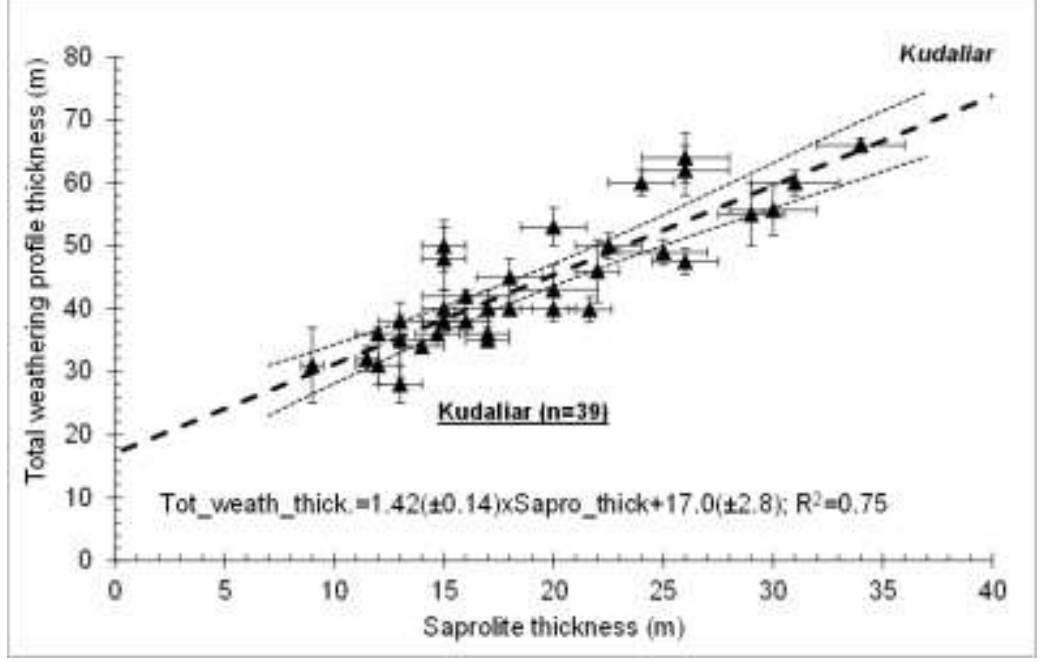

819 Figure 5. Mapping of the weathered layers, Kudaliar watershed. a) Saprolite thickness map. b) Total weathering-profile-thickness map. c) Relationship between saprolite thickness and the entire weathering-profile thickness; dotted lines present the 95\% interval. The inserts present the variograms used for data interpolation (saprolite map $=$ model: spherical, nugget: 10, length: $4500 \mathrm{~m}$, sill: 43 ; total weathering-profile thickness map= model: spherical, nugget: 17, length: $4800 \mathrm{~m}$, sill: 89 ). Contour interval: $4 \mathrm{~m}$. 


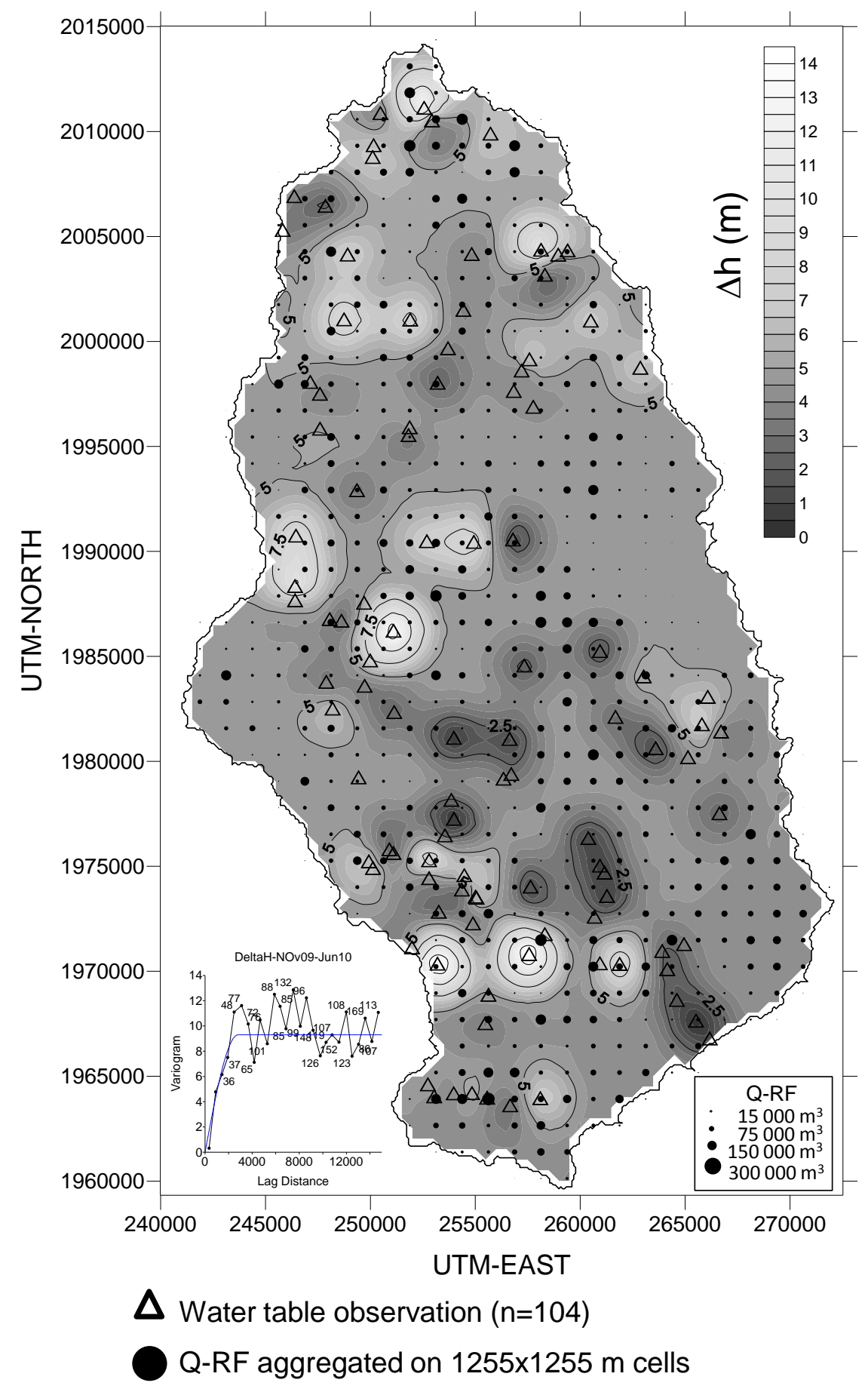

826 Figure 6. Water table fluctuation map ( $\Delta \mathrm{h}$; contours: $2.5 \mathrm{~m}$ and coloured scale) and net 827 groundwater abstraction (Q-RF on $1250 \times 1250 \mathrm{~m}$ cell-size grid), Kudaliar watershed. The 828 insert presents the variogram used for data interpolation (model: spherical, length: $2800 \mathrm{~m}$, 829 sill: 9.3). 


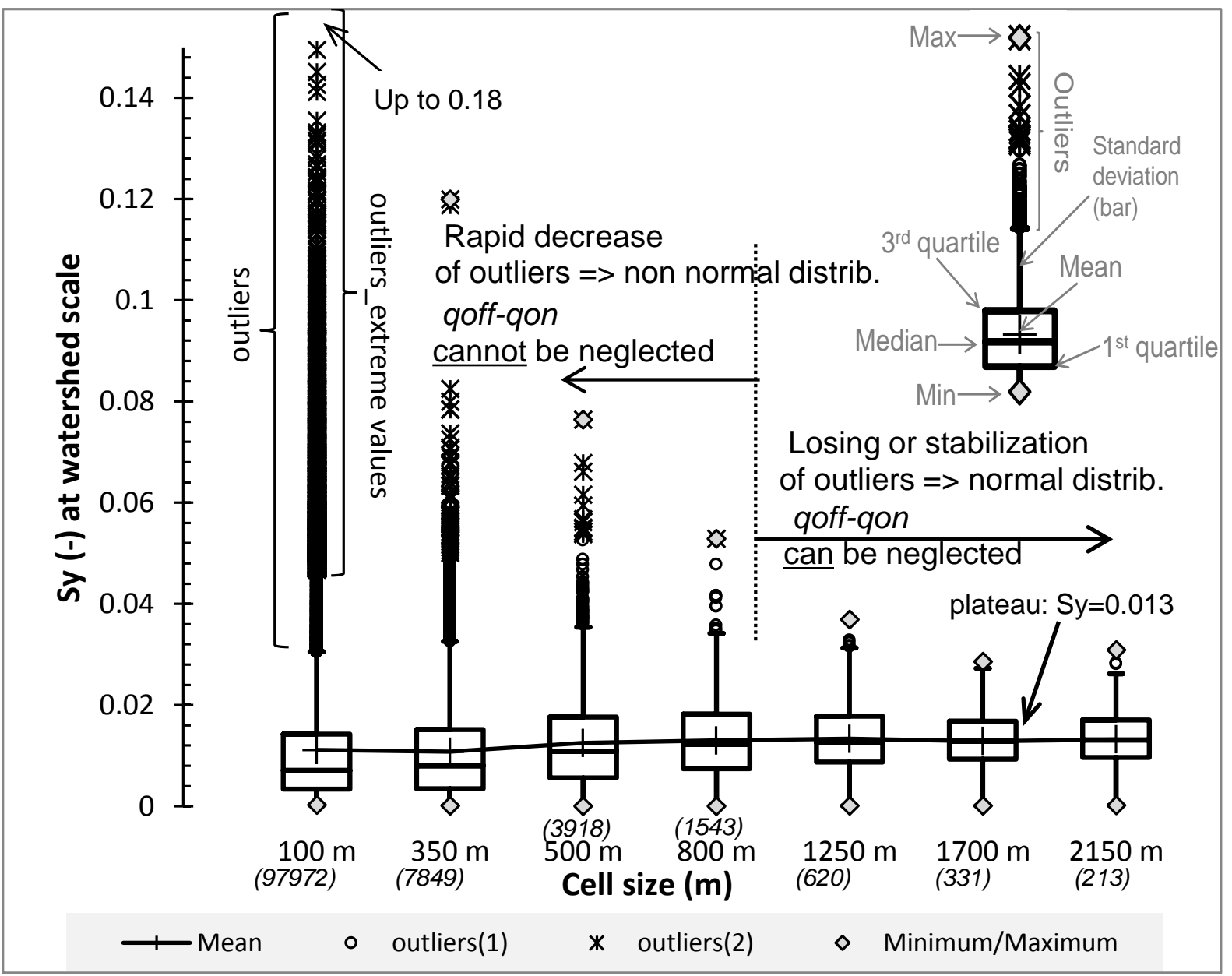

831 Figure 7. Box plots of Sy estimated from computation at various cell sizes (Eq. 2). See insert for legend. The decrease of outliers is used as an indicator to choose the appropriate cell-size for Sy mapping (for that part of the aquifer where water table fluctuates). Kudaliar watershed. 


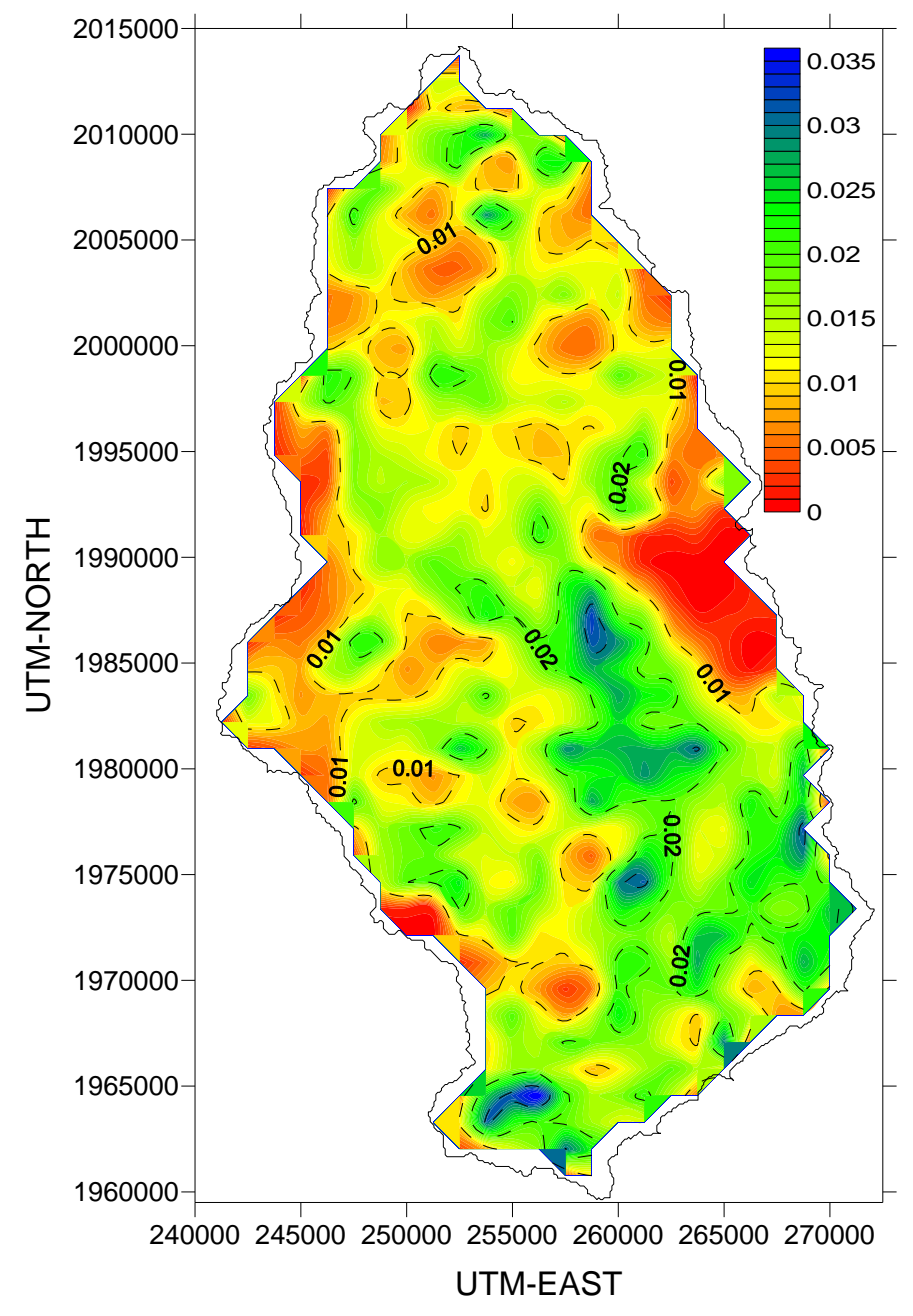

835 Figure 8. Sy map for the zone where water table fluctuates, cell-size 1250x1250 m, Kudaliar watershed. The insert presents the variogram used for data interpolation (model: exponential, length: $4800 \mathrm{~m}$, sill: $3.7 \times 10^{-5}$ ). Cell size $1250 \times 1250 \mathrm{~m}$.

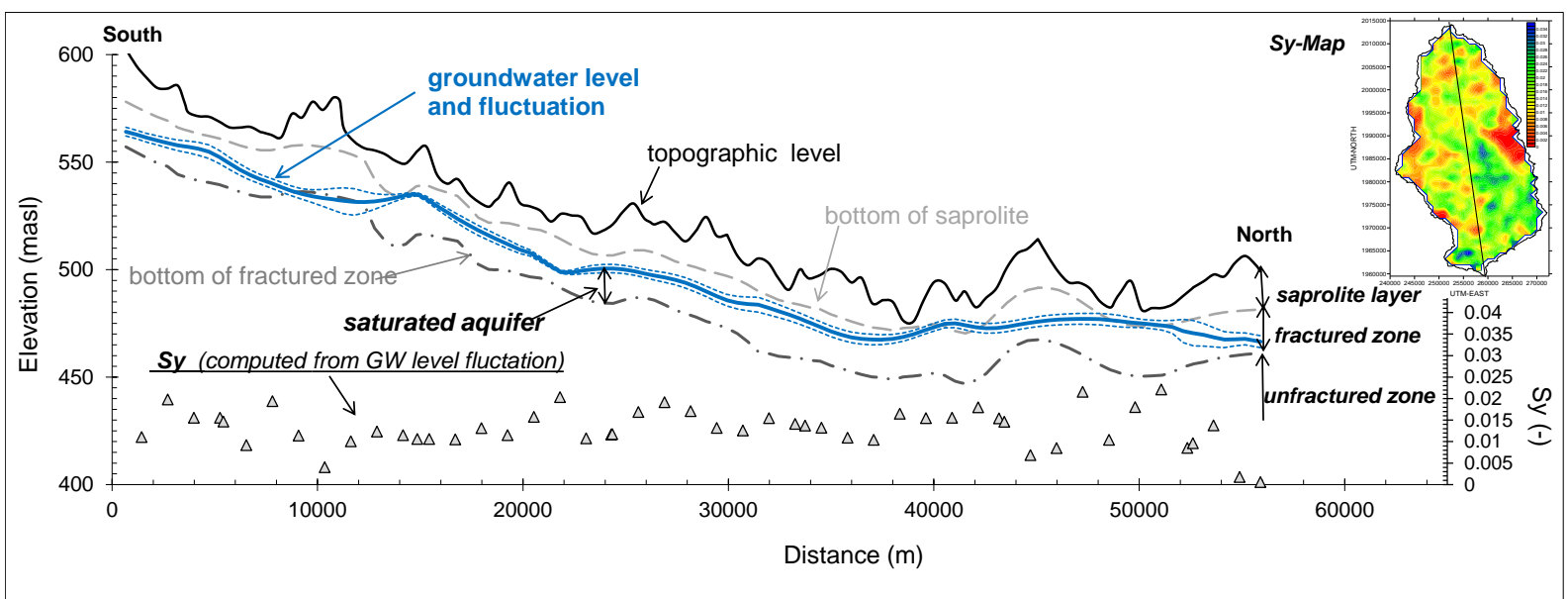

Figure 9. Cross section, Kudaliar watershed. Shown are topographic level, bottom of saprolite layer and of fractured layer, zone where water table fluctuates during the dry season 2010, and corresponding computed Sy-values. The insert map (Sy-map; Fig. 8) presents the location of the cross section. 

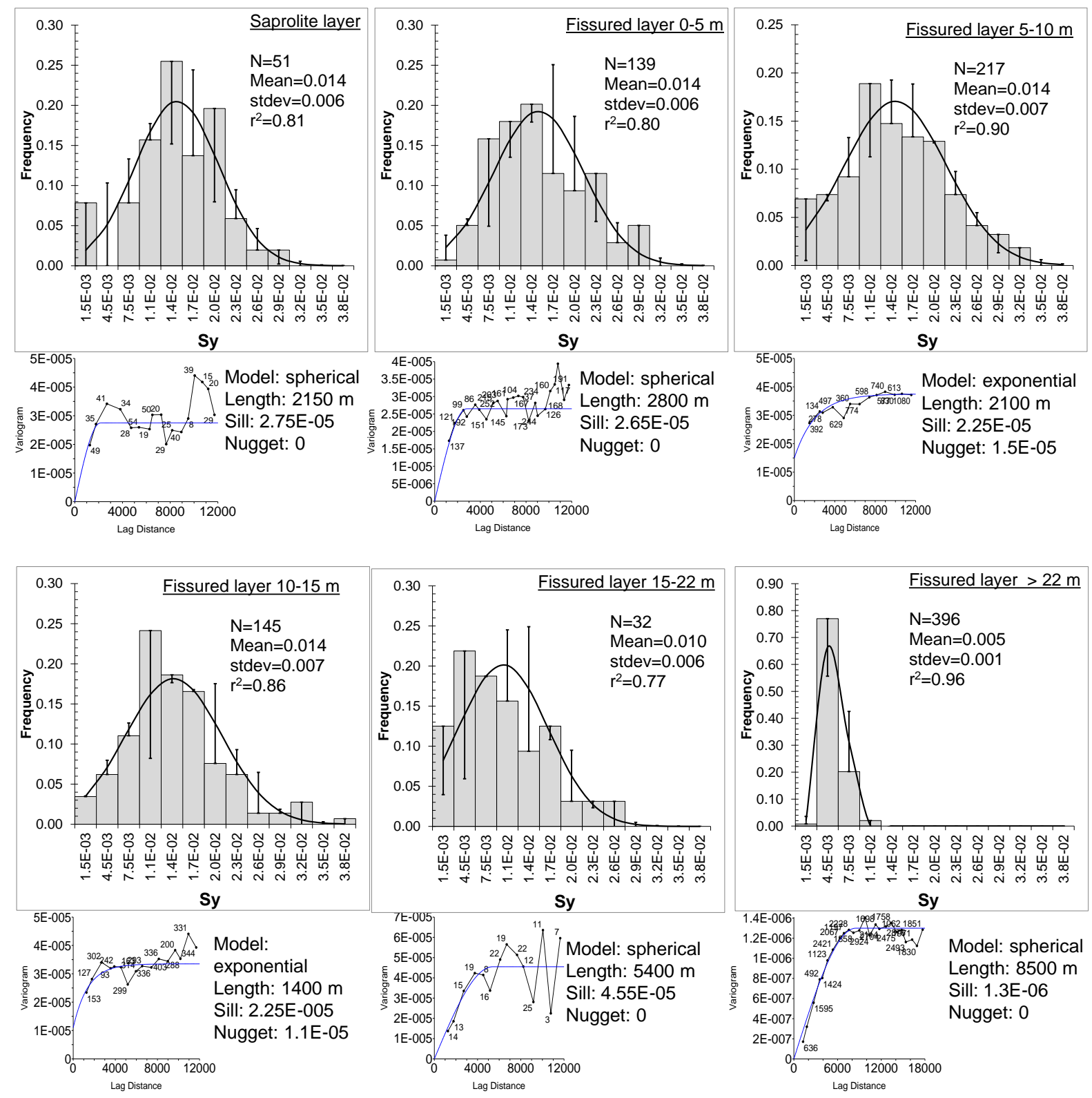

Figure 10. Sy $v s$. depth intervals in the weathering profile for the Kudaliar watershed (one for the saprolite layer and five for the fractured layer). a) Histograms and variograms. 

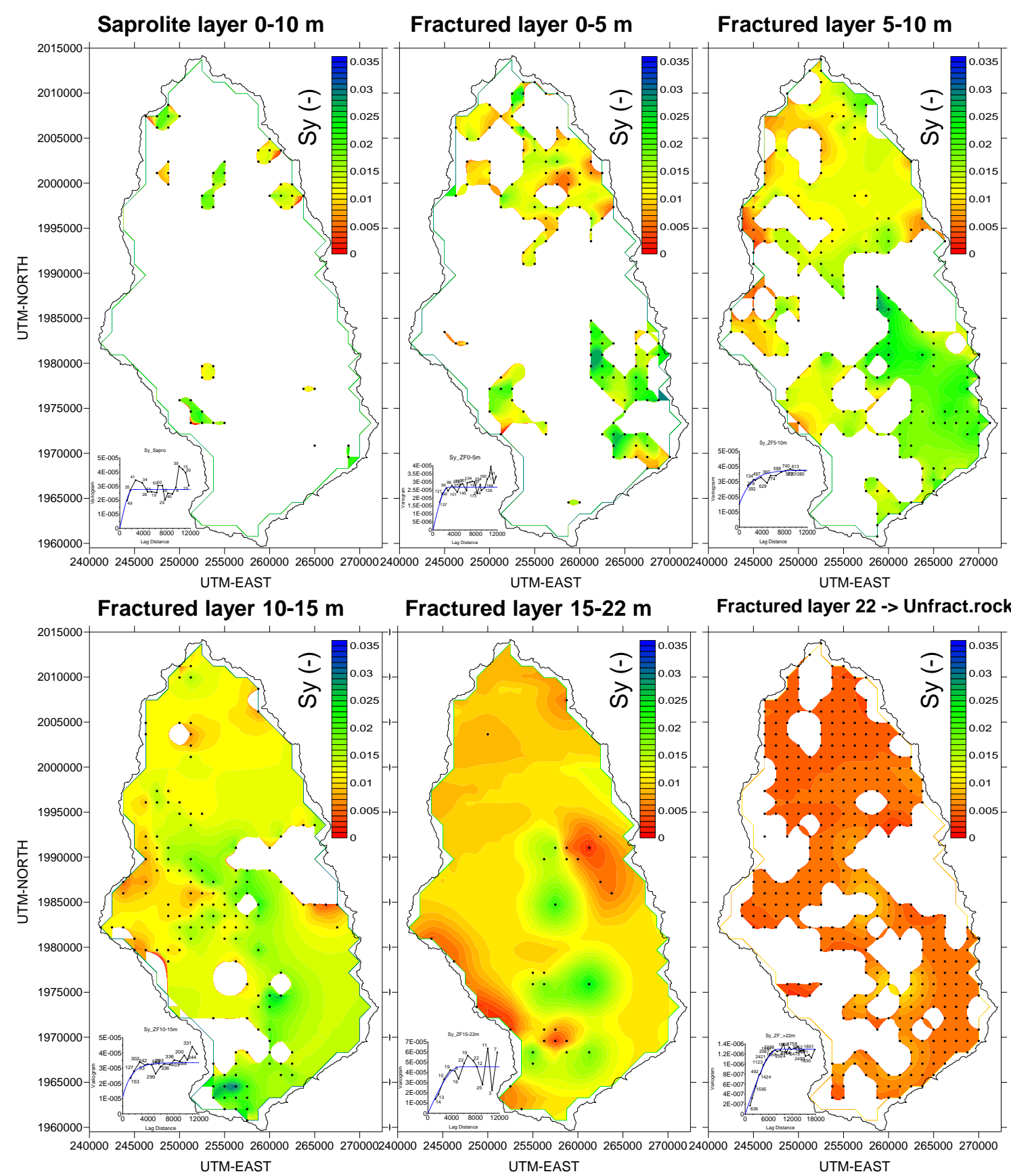

Figure 10. Sy $v s$. depth intervals in the weathering profile for the Kudaliar watershed (one for the saprolite layer and five for the fractured layer). b) Corresponding maps (inserts present variogram used for data interpolation except for the saprolite layer and for the last depthinterval of the fractured zone [ $22 \mathrm{~m}$ to unfractured rock], see text for explanation). Cell size $1250 \times 1250 \mathrm{~m}$. Note that cells of each interval are not necessarily saturated as this depends on both location of the water table and aquifer depth. 
Published in Hydrological Processes. 2017;1-19. DOI: 10.1002/hyp.11187

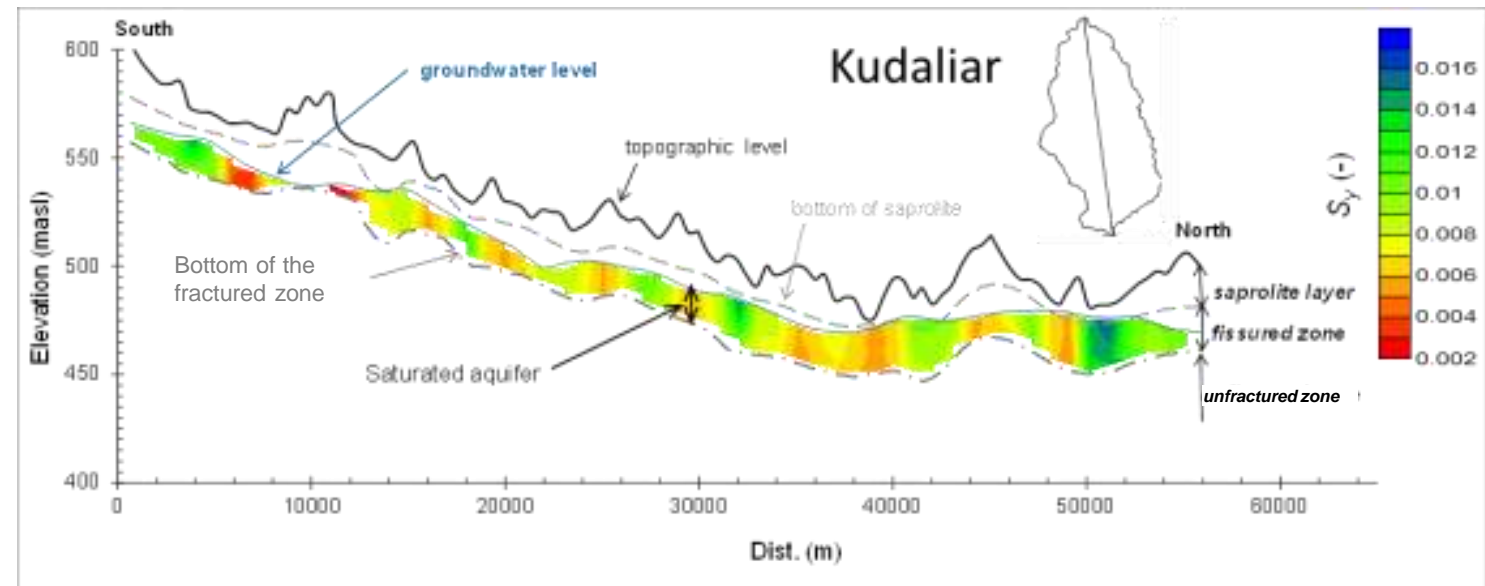

(a)

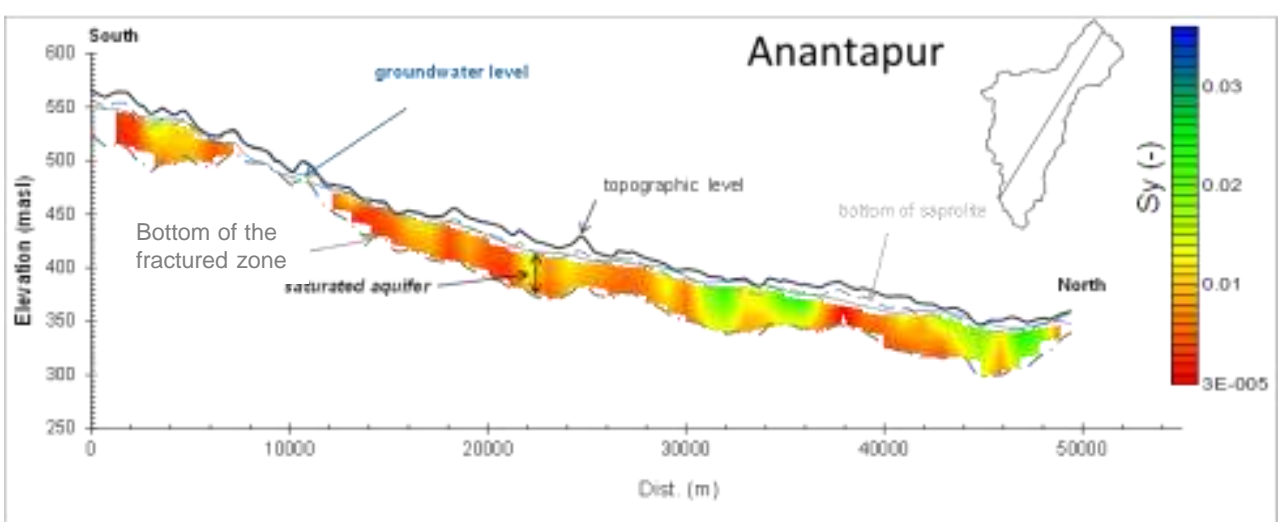

(b)

855 Figure 11. Cross sections of Sy-values for Kudaliar (a) and Anantapur (b) watersheds. The 856 inserted maps locate cross sections. 


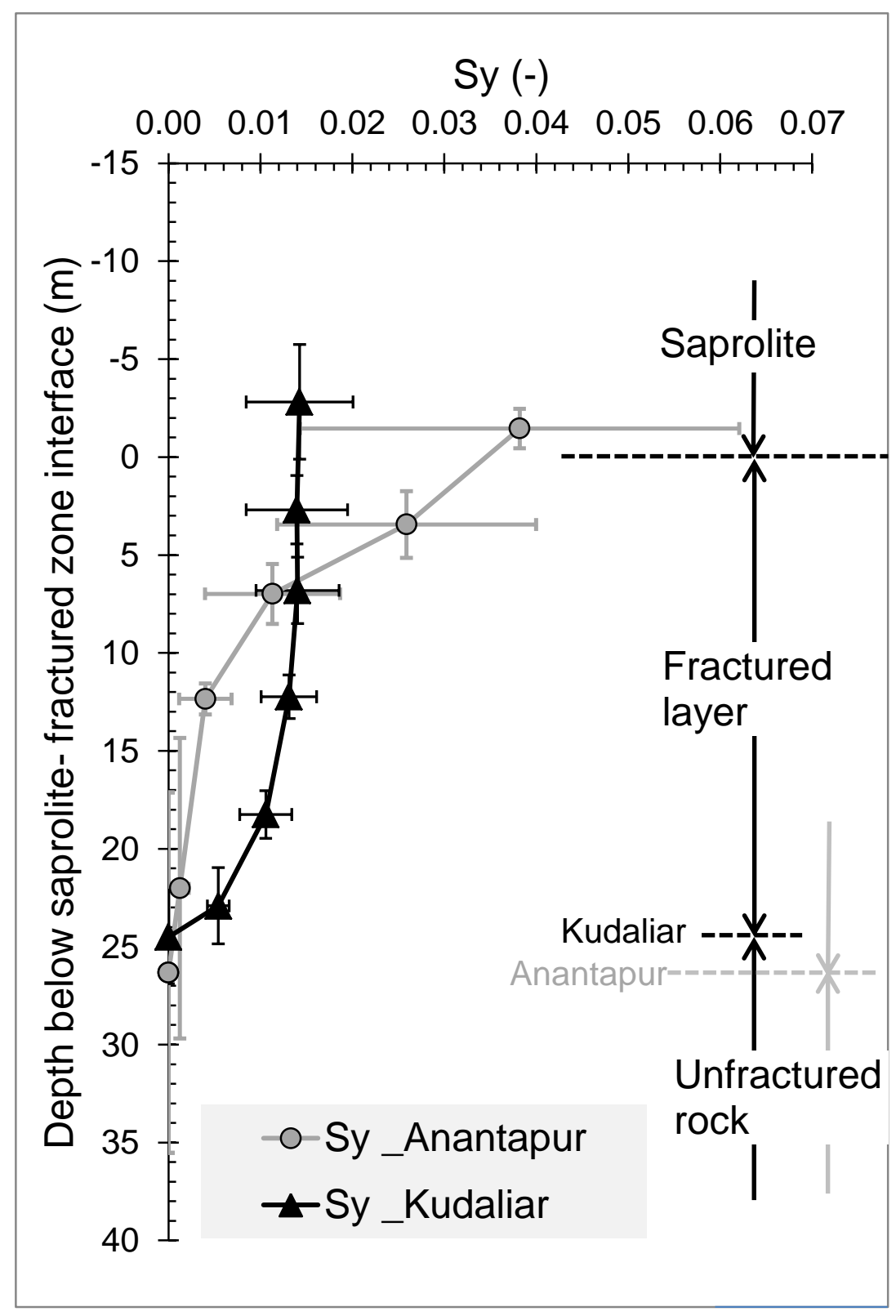

858 Figure 12. Average vertical Sy variations in the weathering profile for both watersheds; bars 859 depict standard deviations. 
Published in Hydrological Processes. 2017;1-19. DOI: 10.1002/hyp.11187
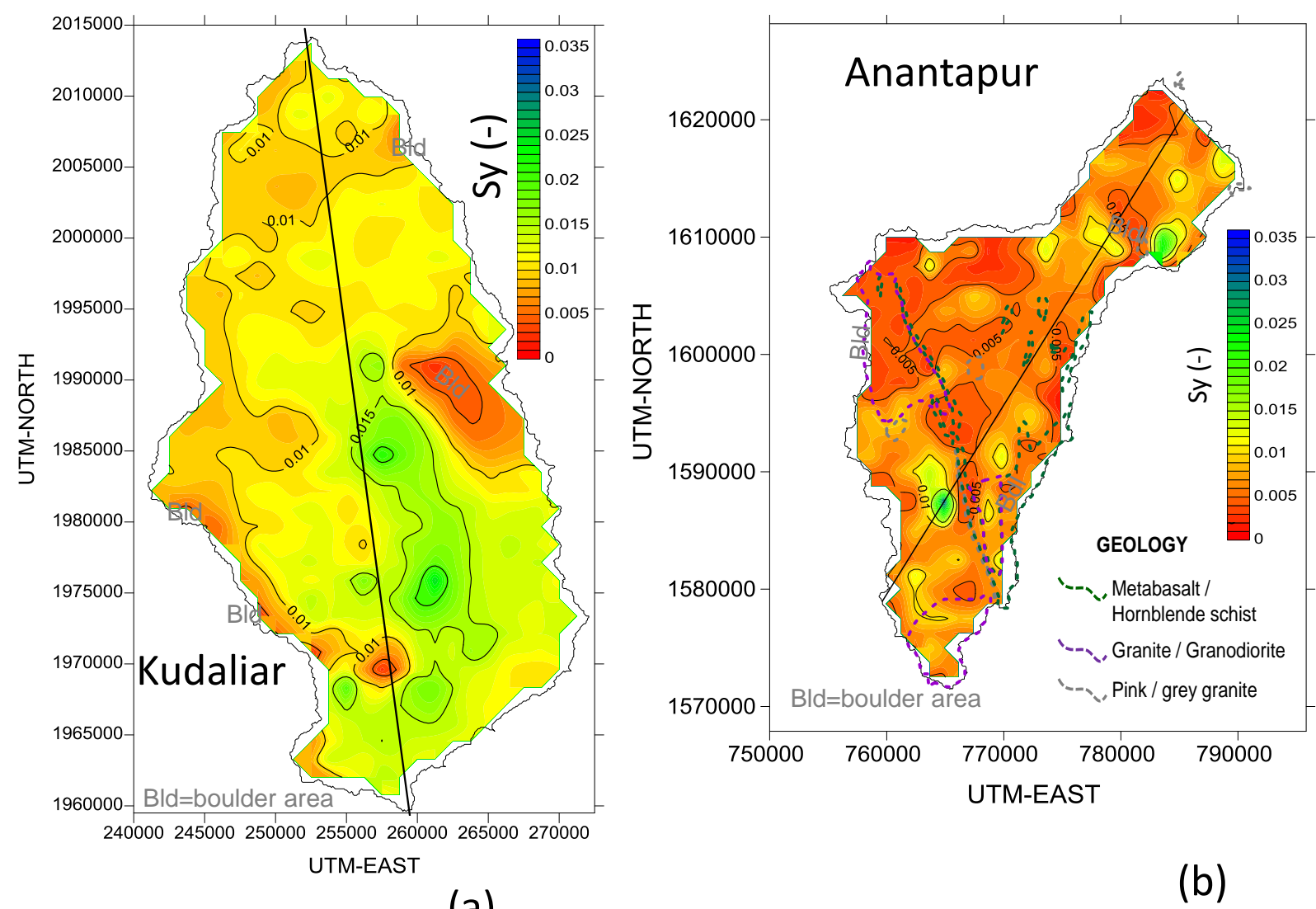

(a)

861 Figure 13. Mean Sy-values for the entire saturated thickness. Kudaliar (a) and Anantapur (b) watersheds. Lines locate cross sections of Fig. 11. Cell size 1250x1250 m. 

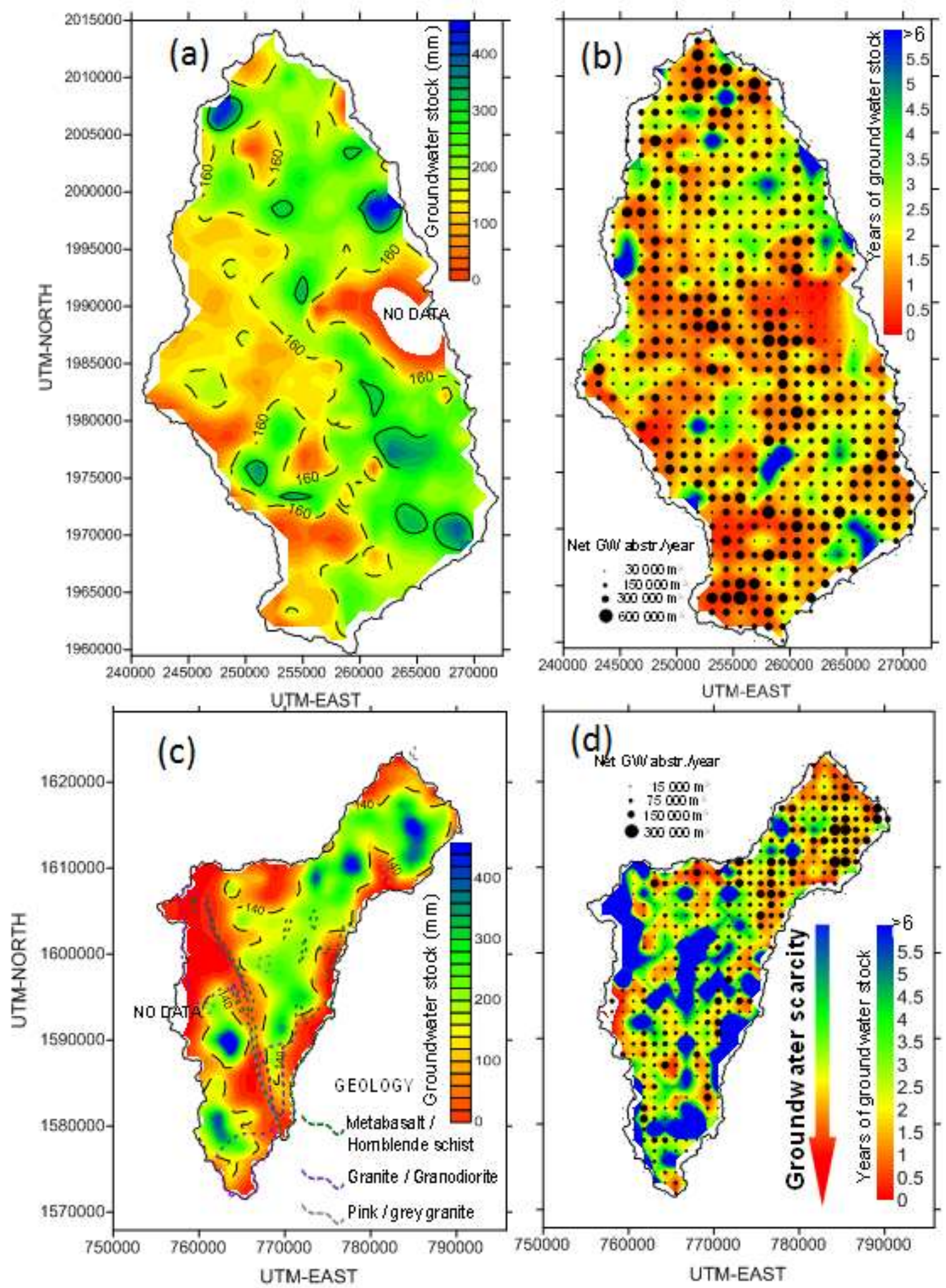

Figure 14. Groundwater storage maps for Kudaliar (a) and Anantapur (c); for Anantapur the main geological unit, gneiss, is not shown (see Fig. 1b). Maps showing groundwater scarcity and vulnerability to overpumping of the aquifer for Kudaliar (b) and Anantapur (d). Cell size $1250 \times 1250 \mathrm{~m}$. 


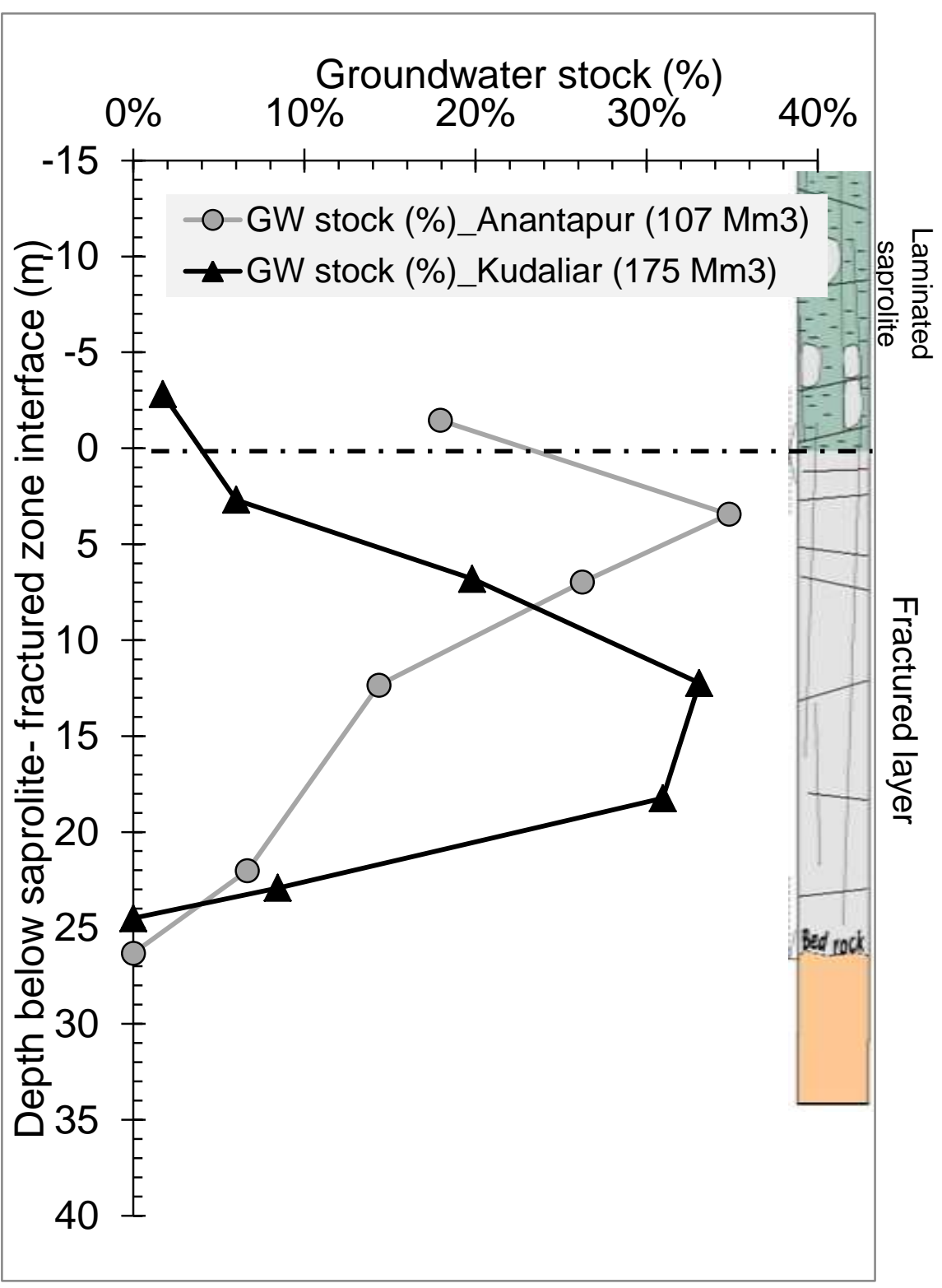

Figure 15. Depth-variation of groundwater storage at the watershed scale, Kudaliar and 870 Anantapur watersheds. 


\section{Tables}

Rainy season (Khariff) 2009 (June 2009-Oct. 2009)

\begin{tabular}{|c|c|c|c|c|c|c|c|c|c|}
\hline \multicolumn{5}{|c|}{ Rainy season (Khariff) 2009 (June 2009-Oct. 2009) } & \multicolumn{3}{|c|}{ Cropping stages } & \multirow[b]{2}{*}{$\begin{array}{l}\text { GW-Abs. } \\
\text { (m3) }\end{array}$} & \multirow[b]{2}{*}{$\begin{array}{l}\text { GW-Abs. } \\
(\mathrm{mm})\end{array}$} \\
\hline Use & $\%$ of the area & $\begin{array}{l}\text { Plot watering } \\
\text { (mm/day) }\end{array}$ & \begin{tabular}{|l|} 
Frequency of \\
irrigation (/day)
\end{tabular} & $\begin{array}{l}\text { \% of plot } \\
\text { concerned by } \\
\text { irrigation }\end{array}$ & $\begin{array}{l}\text { Nursery } \\
\text { (day) }\end{array}$ & $\begin{array}{l}\text { Growing } \\
\text { (day) }\end{array}$ & $\begin{array}{l}\text { Maturation } \\
\text { (day) }\end{array}$ & & \\
\hline Rice & $10.2 \%$ & 8.8 & 1.00 & $100 \%$ & 30 & 90 & 15 & $8.2 \mathrm{E}+07$ & 83.0 \\
\hline Maize & $15.5 \%$ & 9.0 & 0.26 & $7 \%$ & - & 93 & 20 & $2.2 \mathrm{E}+06$ & 2.2 \\
\hline Vegetables & $0.0 \%$ & 9.0 & 0.26 & $100 \%$ & - & 99 & & $1.4 \mathrm{E}+04$ & 0.0 \\
\hline Other crops & $0.0 \%$ & 9.0 & 0.13 & $100 \%$ & - & 116 & & $2.8 \mathrm{E}+03$ & 0.0 \\
\hline Cotton & $19.2 \%$ & 9.0 & 0.15 & $3 \%$ & - & 201 & 30 & $1.6 \mathrm{E}+06$ & 1.6 \\
\hline Domestic & 302703 (inhab.) & 30.0 (I/d/inhab.) & 1.00 & $100 \%$ & - & - & - & $1.4 \mathrm{E}+06$ & 1.4 \\
\hline Total & $45.0 \%$ & & - & - & - & - & - & $8.7 E+07$ & 88.1 \\
\hline
\end{tabular}

Dry season (Rabi) 2010 (Nov. 2009-June 2010)

\begin{tabular}{|c|c|c|c|c|c|c|c|c|c|}
\hline Use & $\%$ of the area & $\begin{array}{l}\text { Plot watering } \\
(\mathrm{mm} / \text { day })\end{array}$ & $\begin{array}{l}\text { Frequency of } \\
\text { irrigation (/day) }\end{array}$ & \begin{tabular}{|l} 
\% of plot \\
concerned by \\
irrigation
\end{tabular} & $\begin{array}{l}\text { Nursery } \\
\text { (day) }\end{array}$ & $\begin{array}{l}\text { Growing } \\
\text { (day) }\end{array}$ & \begin{tabular}{|l} 
Maturation \\
(day)
\end{tabular} & $\begin{array}{l}\text { GW-Abs. } \\
(\mathrm{m} 3)\end{array}$ & $\begin{array}{l}\text { GW-Abs. } \\
(\mathrm{mm})\end{array}$ \\
\hline Rice & $7.2 \%$ & 12.3 & 1.00 & $100 \%$ & 30 & 107 & 15 & $9.5 \mathrm{E}+07$ & 96.6 \\
\hline Maize & $1.9 \%$ & 9.0 & 0.26 & $100 \%$ & - & 93 & 20 & $4.1 \mathrm{E}+06$ & 4.2 \\
\hline Vegetables & $6.9 \%$ & 9.0 & 0.26 & $100 \%$ & & 99 & & $1.5 \mathrm{E}+07$ & 15.8 \\
\hline Other crops & $2.1 \%$ & 9.0 & 0.13 & $100 \%$ & & 116 & & $2.7 \mathrm{E}+06$ & 2.8 \\
\hline Domestic & 302703 (inhab.) & 30.5 (I/d/inhab.) & 1.00 & $100 \%$ & & - & - & $1.4 \mathrm{E}+06$ & 1.4 \\
\hline Total & $18.1 \%$ & & - & - & - & - & - & $1.2 \mathrm{E}+08$ & 120.6 \\
\hline
\end{tabular}

Table1. Groundwater abstraction in Kudaliar watershed $\left(983 \mathrm{~km}^{2}\right)$ during the 2009 rainy season and the 2010 dry season. GW-Abs.: groundwater abstraction in $\mathrm{m}^{3}$ and $\mathrm{mm}$. Plot watering: amount of water brought for irrigation. Cropping stages, for rice only $7 \%$ of the plots are irrigated during the nursery stage (before transplanting the young rice plant with rice

\begin{tabular}{|l|c|c|}
\hline Use & Crf_Rabi & Crf_Khariff \\
\hline Rice & 0.48 & 0.51 \\
\hline Maize & 0.24 & 0.26 \\
\hline Vegetables & 0.24 & 0.26 \\
\hline Other crops & 0.11 & 0.13 \\
\hline Domestic & 0.20 & 0.20 \\
\hline Cotton & not cultivated & 0.13 \\
\hline
\end{tabular}

881 Table 2. Irrigation return-flow coefficients (from Maréchal et al., 2006; Dewandel et al., 
Rainy season (Khariff) 2009 (June 2009-Oct. 2009)

\begin{tabular}{|l|r|r|r|r|}
\hline Use & $R F(\mathrm{~m} 3)$ & $R F(\mathrm{~mm})$ & $Q-R F(\mathrm{~m} 3)$ & $\mathrm{Q}-\mathrm{RF}(\mathrm{mm})$ \\
\hline Rice & $4.2 \mathrm{E}+07$ & 42.3 & $4.0 \mathrm{E}+07$ & 40.7 \\
\hline Maize & $5.6 \mathrm{E}+05$ & 0.6 & $1.6 \mathrm{E}+06$ & 1.6 \\
\hline Vegetables & $3.6 \mathrm{E}+03$ & 0.0 & $1.0 \mathrm{E}+04$ & 0.0 \\
\hline Other crops & $3.7 \mathrm{E}+02$ & 0.0 & $2.5 \mathrm{E}+03$ & 0.0 \\
\hline Cotton & $2.0 \mathrm{E}+05$ & 0.2 & $1.4 \mathrm{E}+06$ & 1.4 \\
\hline Domestic & $2.7 \mathrm{E}+05$ & 0.3 & $1.1 \mathrm{E}+06$ & 1.1 \\
\hline Total & $\mathbf{4 . 3 E + 0 7}$ & $\mathbf{4 3 . 4}$ & $\mathbf{4 . 4 E + 0 7}$ & $\mathbf{4 4 . 8}$ \\
\hline
\end{tabular}

Dry season (Rabi) 2010 (Nov. 2009-June 2010)

\begin{tabular}{|l|r|r|r|r|}
\hline Use & $R F(\mathrm{~m} 3)$ & $R F(\mathrm{~mm})$ & $Q-R F(\mathrm{~m} 3)$ & $Q-R F(\mathrm{~mm})$ \\
\hline Rice & $4.6 \mathrm{E}+07$ & 46.4 & $4.9 \mathrm{E}+07$ & 50.2 \\
\hline Maize & $9.8 \mathrm{E}+05$ & 1.0 & $3.1 \mathrm{E}+06$ & 3.2 \\
\hline Vegetables & $3.7 \mathrm{E}+06$ & 3.8 & $1.2 \mathrm{E}+07$ & 12.0 \\
\hline Other crops & $3.0 \mathrm{E}+05$ & 0.3 & $2.4 \mathrm{E}+06$ & 2.5 \\
\hline Domestic & $2.8 \mathrm{E}+05$ & 0.3 & $1.1 \mathrm{E}+06$ & 1.1 \\
\hline Total & $\mathbf{5 . 1 E + 0 7}$ & $\mathbf{5 1 . 7}$ & $\mathbf{6 . 8 E + 0 7}$ & $\mathbf{6 8 . 9}$ \\
\hline
\end{tabular}

887 Table 3. Net groundwater abstractions for the 2009 rainy season and the 2010 dry season. Q (groundwater abstraction) is taken from Table 1 (GW-Abs.). 